\title{
Sieverdingia gen. nov., S. tortuosa comb. nov., and Diversispora peloponnesiaca sp. nov. in the Diversisporaceae (Glomeromycota)
}

\author{
Janusz Błaszkowski ${ }^{1}$ Piotr Niezgoda ${ }^{1}$ • Jéssica Nunes de Paiva ${ }^{2} \cdot$ Kássia Jéssica Galdino da Silva ${ }^{2}$. \\ Raquel Cordeiro Theodoro ${ }^{3} \cdot$ Khadija Jobim $^{2} \cdot$ Michail Orfanoudakis $^{4} \cdot$ Bruno Tomio Goto $^{2}$
}

Received: 25 May 2019 / Revised: 24 August 2019 / Accepted: 15 October 2019

(C) The Author(s) 2019

\begin{abstract}
Phylogenetic analyses of 18S-ITS-28S nuc rDNA sequences indicated that the arbuscular mycorrhizal fungus originally described as Glomus tortuosum and later transferred to the genus Corymbiglomus represents a separate, previously unrecognized clade at the rank of genus in the family Diversisporaceae (order Diversisporales, phylum Glomeromycota). The analyses located the clade between clades representing the genera Desertispora and Redeckera. Consequently, a new genus, Sieverdingia, was erected, with $S$. tortuosa comb. nov. The unique morphological feature of $S$. tortuosa is the formation of glomoid-like spores with a single-layered spore wall covered with a hyphal mantle. Importantly, the erection of Sieverdingia clarified the definition of Corymbiglomus, which currently consists of three species producing glomoid-like spores with one, three- to four-layered spore wall. The features of the innermost layer, which is hyaline, laminate, flexible to semi-flexible, indicate that it is a synapomorphy of Corymbiglomus. The definitions of Corymbiglomus and its species were emended. Moreover, the distribution of S. tortuosa and the three species of Corymbiglomus was discussed based on own studies, literature data, and molecular sequences deposited in public databases. We concluded that the distribution of S. tortuosa and C. globiferum known in environmental studies based on their partial 28S nuc rDNA sequences only may be understated because the main molecular characteristics distinguishing these species reside outside the $28 \mathrm{~S}$ region. Finally, we described a new species in the genus Diversispora originating from Mediterranean dunes of the Peloponnese peninsula, Greece. The same phylogenetic analyses mentioned above indicated that the closest relative of the new species, producing dark-coloured spores, is D. clara, whose spores are creamy white at most.
\end{abstract}

Keywords Arbuscular mycorrhizal fungi $\cdot$ Morphology $\cdot$ Molecular phylogeny $\cdot 18$ S-ITS-28S nuc rDNA

Section Editor: Marco Thines

Janusz Błaszkowski

janusz.blaszkowski@zut.edu.pl

Piotr Niezgoda

np12457@zut.edu.pl

Jéssica Nunes de Paiva

jessicapaivapn@hotmail.com

Raquel Cordeiro Theodoro

raquel.ctheodoro@gmail.com

Khadija Jobim

khadija_jobim@hotmail.com

Michail Orfanoudakis

morfan@fmenr.duth.gr
Bruno Tomio Goto

brunogoto@hotmail.com

1 Department of Ecology, Protection and Shaping of Environment, West Pomeranian University of Technology, Słowackiego 17, PL71434 Szczecin, Poland

2 Departamento de Botânica e Zoologia, Universidade Federal do Rio Grande do Norte, Campus Universitário, Natal, RN 59072-970, Brazil

3 Departamento de Biologia Celular e Genética, Universidade Federal do Rio Grande do Norte, Campus Universitário, Natal, RN 59072-970, Brazil

4 Forest soil Laboratory, Department of Forestry and Management of the Environment and Natural Resources, Democritus University of Thrace, Pandazidou 193, 68200 Orestiada, Greece 


\section{Introduction}

The phylum Glomeromycota C. Walker \& A. Schüßler, comprising arbuscular mycorrhizal fungi (AMF), is currently represented by ca. 315 species (http:// glomeromycota.wixsite.com/lbmicorrizas/cpia). About $57 \%$ of these species produce glomoid or glomoid-like spores, and the species are distributed in 25 genera belonging to nine families of the Glomeromycota. The glomoid and glomoid-like spores arise blastically at the tip of a cylindrical or funnel-shaped sporogenous hypha, like spores of Glomus macrocarpum Tul. \& C. Tul., the type species of the genus Glomus Tul. \& C. Tul. emend. Oehl, G.A. Silva \& Sieverd. and the Glomeromycota (Clements and Shear 1931; Oehl et al. 2011), and their subcellular structure contains only one spore wall continuous with the subtending hyphal wall (Błaszkowski et al. 2018a, 2018b; Jobim et al. 2019).

The fungus originally described as G. tortuosum N.C. Schenck \& G.S. Sm. is one of the few species (15, of which probably not all are certain species) of the Glomeromycota, which produces glomoid-like spores singly or in unorganized clusters (with randomly distributed spores), and the spores have a spore wall consisting of only one coloured layer (Schenck and Smith 1982). Based on phylogenetic analyses of sequences of the partial large subunit (28S) nuc rDNA, Błaszkowski and Chwat (2013) transferred G. tortuosum, along with G. globiferum Koske \& C. Walker, to Corymbiglomus Błaszk. \& Chwat in the family Diversisporaceae C. Walker \& A. Schüßler, order Diversisporales C. Walker \& A. Schüßler, and renamed the species as C. tortuosum (N.C. Schenck \& G.S. Sm.) Błaszk. \& Chwat and C. globiferum (Koske \& C. Walker) Błaszk. \& Chwat. The genus Corymbiglomus, with the type species $C$. corymbiforme Błaszk., was previously erected following phylogenetic analyses of partial $28 \mathrm{~S}$ sequences of G. corymbiforme Błaszk. (Błaszkowski 2012). In the presented phylogenetic tree (Fig. 1; Błaszkowski and Chwat 2013), each of the species was represented by only one partial 28S sequence and the three sequences clustered in a sister clade to a clade representing the genus Diversispora C. Walker \& A. Schüßler. Interestingly, the three-species clade consisted of two subclades, one with sequences of $C$. corymbiforme and C. globiferum, and the second with a sequence of $C$. tortuosum.

Unfortunately, in the analyses discussed above, no sequence of Redeckera spp. was included. However, the ecology and all other morphological features of Redeckera spp. and C. tortuosum differ fundamentally (Redecker et al. 2007; Schenck and Smith 1982; Oehl et al. 2011). Importantly, our preliminary phylogenetic analyses of available sequences of the partial small subunit $(18 \mathrm{~S})$, internal transcribed spacer $($ ITS1-5.8S-ITS2 $=$ ITS $)$ and partial 28S (= 18S-ITS-28S) nuc rDNA segment or part thereof of representatives of all glomoid-like sporeproducing genera of the Diversisporaceae sensu Redecker et al. (2013) suggested that $C$. tortuosum does not belong to Corymbiglomus, but it represents a yet undescribed genus in the Diversisporaceae, a hypothesis also postulated by Medina et al. (2014).

In the same paper, Medina et al. (2014) described a new species in Corymbiglomus, C. pacificum Oehl et al., whose spores were not surrounded by a hyphal mantle, as spores of the three species discussed above. Most importantly, the researches stated that the subcellular structure of the glomoid-like spores of C. pacificum consists of two spore walls and suggested that spores of C. corymbiforme and C. globiferum are also two-walled. Interestingly, $C$. corymbiforme was originally characterized (as G. corymbiforme) to produce spores with a single spore wall consisting of three layers (Błaszkowski 1995). The original description of C. globiferum (as G. globiferum) also testifies that its spores have one spore wall (Koske and Walker 1986). Moreover, our observations of the microphotographs of spores of C. pacificum published by Medina et al. (2014) suggested that spore wall 2 of C. pacificum sensu Medina et al. (2014) is not a separate spore wall and does not arise identically as, for example, spore wall 2 of species of Pacispora (Błaszkowski 2012).

Literature data and BLAST searches testify that species of Diversispora occur in different cultivated and natural habitats and have a worldwide distribution, as well as they suggest that many fungi of this genus remain undescribed (Sridhar and Beena 2001; Schüßler et al. 2011; Błaszkowski et al. 2015c; Symanczik et al. 2018). We extracted from a pot trap culture glomoid-like spores, whose morphological features of the subtending hypha and the spore wall at the spore base corresponded to those defined by Oehl et al. (2011) as characteristic for diversisporoid spores of Diversispora. In addition, other morphological characters of these spores suggested that they represent an undescribed Diversispora sp.

Considering the doubts and suppositions discussed above, the aims of our further studies were (i) to check the phylogenetic position of the four described species of Corymbiglomus among other glomoid-like spore-producing taxa of the family Diversisporaceae based on more convincing molecular information; (ii) to definitively define the subcellular structure of spores of these species; (iii) to emend the diagnostic description of the genus Corymbiglomus, if necessary; and (iv) to confirm the novelty of the putative undescribed Diversispora sp. by growing it in single-species cultures, determining its phylogenetic position among molecularly sequenced glomoid-like spore-producing members of the Diversisporaceae and by characterizing its morphology. 


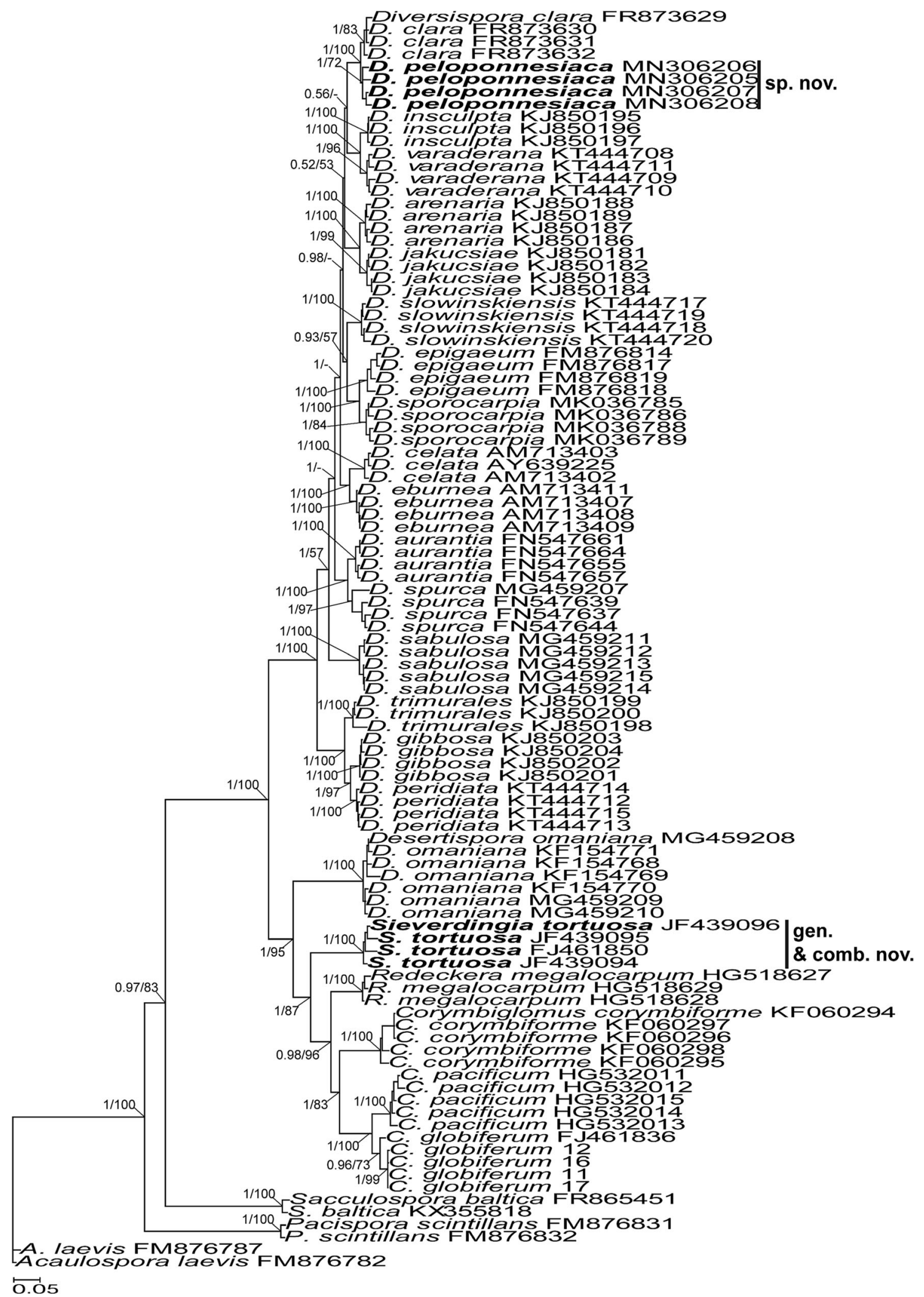

Fig. 1 A 50\% majority rule consensus phylogram inferred from a Bayesian analysis of $18 \mathrm{~S}-\mathrm{ITS}-28 \mathrm{~S}$ nuc rDNA sequences of Diversispora peloponnesiaca and Sieverdingia tortuosa, as well as 24 other species of AMF, including Acaulospora laevis, Pacispora scintillans, and Sacculospora baltica as outgroup. The Bayesian posterior probabilities $\geq 0.50$ and ML bootstrap values $\geq 50 \%$ are shown near the branches, respectively. Bar indicates 0.5 expected change per site per branch 


\section{Materials and methods}

\section{Origin of study material, establishment and growth of the fungi in trap and single-species cultures, extraction of spores, and staining of mycorrhizal structures}

We characterized the morphology of the fungus originally described as $G$. tortuosum based on its original description (Schenck and Smith 1982), its features described and illustrated by Dr. J.B. Morton (http://fungi.invam.wvu.edu/the-fungi/ classification/diversisporaceae/diversispora/tortuosum.html), spores extracted from a pot trap culture and field-collected rhizosphere soil samples, as well as based on examination of type material (OSC\#40251) used to describe the fungus by Schenck and Smith (1982). The trap culture was inoculated with the rhizosphere soil of Ammophila breviligulata Fern. (Poaceae Barnh.) that had colonized maritime sand dunes of New Jersey, USA. The soil sample was collected by Dr. M. Tadych in August 2000. Unfortunately, the geographical position of the sampled site was not determined. All attempts at growing the fungus in single-species cultures established from spores extracted from the trap culture failed. The rhizosphere field soils were collected from Tabebuia roseo-alba (Ridl.) Sandw. (Bignoniaceae Juss.) and Guazuma ulmifolia Lam. [Sterculiaceae (DC.) Bartl.] colonizing sand dunes of the city of Mataraca, Paraiba State, Northeast Brazil $\left(6^{\circ} 28^{\prime} 20^{\prime \prime}-6^{\circ} 30^{\prime}\right.$ $00^{\prime \prime}$ S, $34^{\circ} 55^{\prime} 50^{\prime \prime}-34^{\circ} 57^{\prime} 10^{\prime \prime} \mathrm{W}$; de Souza et al. 2013). The predominant geomorphological formation of the sampled site is clay-sand sedimentary rocks overlaid by fixed dunes, up to $100 \mathrm{~m}$ high. The area has a tropical rainy climate (Am type according to Koppen's classifications; Peel et al. 2007), $25^{\circ} \mathrm{C}$ annual average temperature and $1700 \mathrm{~mm}$ average annual rainfall (Oliveira-Filho and Carvalho 1993).

Spores of $C$. corymbiforme examined in this study were extracted from field-collected rhizosphere soil samples and single-species cultures established from spores collected from trap cultures. The trap cultures were inoculated with the rhizosphere soil samples taken from Ammophila arenaria (L.) Link growing in dunes of the Baltic Sea. The dunes are located

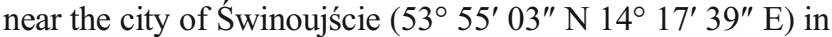
north-western Poland. The climate of Świnoujście is temperate, with an annual sum of rainfall and a mean annual temperature of $550 \mathrm{~mm}$ and $8.92{ }^{\circ} \mathrm{C}$, respectively (https://pl. wikipedia.org/wiki/Świnoujście). All soil samples were collected by J. Błaszkowski in the years 1993-2015.

Corymbiglomus globiferum was characterized here based on its original description (Koske and Walker 1986), the description and pictures presented by Dr. J.B. Morton (http:// fungi.invam.wvu.edu/the-fungi/classification/ diversisporaceae/diversispora/globiferum.html), and spores extracted from trap cultures. The cultures were inoculated with the rhizosphere soils of Cyperus crassipes Vahl
(Cyperaceae Juss.) and Euploca polyphyla (Lehm.) J.I.M. Melo \& Semir (Boraginaceae Juss.) growing in sand dune soils located near the city of Galinhos and in the Reserva de Desenvolvimento Sustentável Estadual Ponta do Tubarão in the Guamaré Municipality (RDSE Ponta do Tubarão), Rio Grande do Norte State, respectively, Brazil. The C. crassipes soil was collected by J.N. de Paiva and K. Jobim in April 2017, and E. polyphyla was sampled by K.J.G da Silva and R.C. Theodoro in June and November 2015. The areas of the city of Galinhos and the RDSE Ponta do Tubarão are ca. $342 \mathrm{~km}^{2}$ and $1.29 \mathrm{~km}^{2}$, respectively, and both are located northwest of the city of Natal $\left(78^{\circ} 02^{\prime} \mathrm{S}, 94^{\circ} 37^{\prime} \mathrm{W}\right.$ and $5^{\circ}$ $5^{\prime} 3.55^{\prime \prime} \mathrm{S}, 36^{\circ} 28^{\prime} 19.13^{\prime \prime} \mathrm{W}$, respectively). The typical biome of these areas is "restinga", which consists mainly of plant species from the families Cyperaceae and Poaceae (Oliveira Filho and Carvalho 1993). According to Koppen's classifications (Peel et al. 2007), the region has a tropical humid climate (type Afi), with an oscillating temperature of $21^{\circ} \mathrm{C}$ and $30^{\circ} \mathrm{C}$ (av. $26.1{ }^{\circ} \mathrm{C}$ ) and an average annual rainfall between 10 and $170 \mathrm{~mm}$.

The morphology of C. pacificum was determined in this study based on the original description of the species (Medina et al. 2014) and its holotype and isotype specimens loaned from the herbarium of ETH Zürich $(Z+Z T)$, Switzerland.

Spores of the putative new species of Diversispora were originally extracted from a trap culture inoculated with the rhizosphere soil of $A$. arenaria. Subsequently, the spores were used to establish single-species cultures of the fungus. In the field, A. arenaria colonized Mediterranean Sea dunes of the beach Voidokoilia ( $36^{\circ} 57^{\prime} 46^{\prime \prime} \mathrm{N} 21^{\circ} 39^{\prime} 45^{\prime \prime}$ E) located on the Peloponnese peninsula, Greece. The climate of the sampled site is warm, with an annual sum of rainfall of $493.8 \mathrm{~mm}$ and temperature ranging from $7-14{ }^{\circ} \mathrm{C}$ (winter) to $21-34{ }^{\circ} \mathrm{C}$ (summer) (http:/www.hnms.gr/emy/el/; https://www. meteoblue.com/en/weather/forecast/modelclimate/pylos greece_255293). Dune soils of the site have a $\mathrm{pH}$ of 7.64-8.06 and are rich in $\mathrm{Mg}$ and $\mathrm{Na}$, whose contents are ca. 74.025 and $72.343 \mathrm{mg} / \mathrm{kg}$, respectively. The soil sample was collected by Dr. Dimitris Arrianas on July 18, 2012.

The methods used to establish trap and single-species cultures of the four species discussed here, the growing conditions of these cultures, and the methods of spore extraction and mycorrhizal staining were as those described previously (Błaszkowski et al. 2012).

\section{Microscopy and nomenclature}

Except for C. pacificum, the morphological features of spores and the phenotypic and histochemical characters of spore wall layers of the other species discussed here were characterized based on at least 50-100 spores of each species mounted in water, lactic acid, polyvinyl alcohol/ 
lactic acid/glycerol (PVLG, Omar et al. 1979), and a mixture of PVLG and Melzer's reagent $(1: 1, \mathrm{v} / \mathrm{v})$. Spores of C. pacificum were characterized based on the original description of this species (Medina et al. 2014) and specimens permanently mounted on microscope slides loaned from the mycological herbarium of ETH Zurich $(Z+Z T)$, Switzerland. The preparation of spores for study and photography were as those described previously (Błaszkowski 2012; Błaszkowski et al. 2012). Types of spore wall layers are those defined by Błaszkowski (2012), and Walker (1983). Colour names are from Kornerup and Wanscher (1983). Nomenclature of fungi and the authors of fungal names are from the Index Fungorum website http://www. indexfungorum.org/AuthorsOfFungalNames.htm. The terms glomerospores and glomerocarps were used for spores and fruit bodies, respectively, produced by AMF, as Goto and Maia (2006) and Jobim et al. (2019) proposed.

Voucher specimens of $C$. corymbiforme, C. globiferum, the fungus originally described as G. tortuosum, and the new species [spores mounted in PVLG and a mixture of PVLG and Melzer's reagent $(1: 1, \mathrm{v} / \mathrm{v})$ on slides] were deposited at the Herbarium of the Federal University of Rio Grande do Norte [UFRN-Fungos Herbarium; vouchers from type of G. tortuosum (UFRN-Fungos 3165) and C. globiferum (UFRN-Fungos 3166, 3167)], ETH Zurich, Switzerland (holotype of $D$. peloponnesiaca), and the Department of Ecology, Protection and Shaping of Environment (DEPSE), West Pomeranian University of Technology, Szczecin (isotypes of D. peloponnesiaca and specimens of the other three species mentioned above).

\section{Molecular phylogeny, DNA extraction, polymerase chain reaction, cloning, and DNA sequencing}

Genomic DNA of C. globiferum and the putative Diversispora sp. was extracted from eight single spores of each fungus. The origin of spores of both species was presented above. Details of the treatment of the spores prior to polymerase chain reactions (PCRs), the conditions, and primers used in the PCRs to obtain 18S-ITS-28S sequences were as those described in Błaszkowski et al. (2015a, 2015b), Krüger et al. (2009), and Symanczik et al. (2014). Cloning and sequencing of PCR products to obtain 18S-ITS-28S sequences of $C$. globiferum and the potentially new Diversispora sp. were performed as described by Błaszkowski et al. (2015a). The sequences were deposited in GenBank (MN306205MN306208).

Unfortunately, many attempts to obtain sequences of the largest subunit of RNA polymerase II $(R P B 1)$ of $C$. globiferum failed, despite nested PCRs being performed in conditions and with primers that allowed obtaining RPBI sequences of $C$. corymbiforme (Symanczik et al. 2018).

\section{Sequence alignment and phylogenetic analyses}

BLAST queries indicated that our 18S-ITS-28S sequences of the diversisporoid fungus sensu Oehl et al. (2011) represent an undescribed species of Diversispora. Subsequently, in order to clarify the doubts regarding the molecular phylogenies of the four so far described species of Corymbiglomus, i.e. C. corymbiforme, C. globiferum, C. pacificum and C. tortuosum, and to determine the phylogenetic position of the new species within the genus Diversispora, an alignment was assembled that consisted of 93 sequences of the $18 \mathrm{~S}-$ ITS-28S segment and eight partial $28 \mathrm{~S}$ sequences. These sequences characterized 23 species, including our new Diversispora sp., belonging to four described genera of the Diversisporaceae and three species that served as outgroup. Of the eight partial $28 \mathrm{~S}$ sequences, three characterized C. globiferum, C. tortuosum, and Diversispora celata C. Walker, Gamper \& A. Schüßler, and five belonged in C. pacificum. The partial $28 \mathrm{~S}$ sequences of $C$. globiferum and C. tortuosum (both treated as members of the genus Diversispora C. Walker \& A. Schüßler; http://fungi.invam. wvu.edu/the-fungi/classification/diversisporaceae/ diversispora/tortuosum.html; http://fungi.invam.wvu.edu/thefungi/classification/diversisporaceae/diversispora/globiferum. html) were obtained from DNA of spores extracted from cultures grown at INVAM. The outgroup was represented by two 18S-ITS-28S sequences each of single species of the three most closely related families of the Diversisporaceae sensu Redecker et al. (2013), i.e. Acaulosporaceae J.B. Morton \& Benny (represented by A. laevis Gerd. \& Trappe), Pacisporaceae C. Walker et al. [P. scintillans (S.L. Rose \& Trappe) Sieverd. et al.], and Sacculosporaceae Oehl et al. [S. baltica (Błaszk., Madej \& Tadych) Oehl et al.]. Identity values of the newly obtained $18 \mathrm{~S}-\mathrm{ITS}-28 \mathrm{~S}$ sequences of $C$. globiferum and the new Diversispora sp. were calculated using BioEdit (Hall 1999). With the same program, we calculated the percentage divergence of a sequence of each of the four species of Corymbiglomus and the Diversispora sp. treated separately from a directly neighbouring sequence of the closest relatives of these fungi, as well as the divergence of all analyzed sequences of each species of Corymbiglomus and the new Diversispora sp. from all sequences clustered in sister species or generic clades of these five species (Fig. 1). All comparisons were performed on sequences of the same length.

The sequence set was aligned with MAFFT v. 7 using the auto option (http://mafft.cbrc.jp/alignment/server/). Indels were coded by means of the simple indel coding algorithm (Simmons et al. 2001) as implemented in GapCoder (Young and Healy 2003), and this binary character set was added to the nucleotide alignment, as described and justified in Błaszkowski et al. (2014). The phylogenetic position of the four species of Corymbiglomus and the new Diversispora sp. 
within the Diversisporaceae was reconstructed from Bayesian inference (BI) and maximum likelihood (ML) phylogenetic analyses of the alignment. The BI analysis was conducted with MrBayes 3.1.2 (Huelsenbeck and Ronquist 2001). The nucleotide substitution model used in this analysis was GTR, which was selected by jModelTest (Posada 2008), considering the selection of Akaike criterion. Four Markov chains were run for 5,000,000 generations, sampling every 100 steps, with a burn-in at 7500 sampled trees. The ML analysis was carried out with the raxmlGUI (Silvestro and Michalak 2012) implementation of RAxML (Stamatakis 2014) with the GTRGAMMA algorithm. A rapid bootstrap analysis with 1000 replicates was used to determine the support of branches. In both BI and ML analyses, the alignment [the nucleotide alignment plus the binary (indel) character set] was divided into four partitions, knowing that analyses of partitioned data generally increase the accuracy of phylogenetic reconstruction (Lanfear et al. 2012; Nagy et al. 2012). The generated phylogenetic tree was visualized and edited in MEGA6 (Tamura et al. 2013).

\section{Results}

\section{General data and phylogeny}

The analyzed sequence alignment had a length of 2063 characters, of which 838 and 755 were variable and parsimony informative, respectively. The identity values of the four 18S-ITS-28S sequences of C. globiferum and four 18SITS-28S sequences of $D$. peloponnesiaca ranged from 99.6 to $99.9 \%$ and from 97.6 to $98.9 \%$, respectively.

Bayesian and ML analyses of the alignment generated trees, in which the position of main clades (five at the rank of genus) to each other and the species composition of sister clades of these generic clades were identical. One of these generic clades contained only sequences of the fungus originally described as G. tortuosum (Fig. 1), and this clade was located between the Desertispora and Redeckera clades. Another generic clade clustered sequences of C. corymbiforme, C. globiferum, and C. pacificum, and this clade was sister to a clade with sequences of $R$. megalocarpum. In the Corymbiglomus clade, C. globiferum and C. pacificum clustered in two separate sister subclades. The generic clade with $G$. tortuosum obtained full supports in both BI and ML analyses. The Corymbiglomus clade was fully $(\mathrm{BI}=1.0)$ or strongly $(\mathrm{ML}=83 \%)$ supported.

The divergences of the neighbouring sequences C. tortuosum JF439096 from Desertispora omaniana MG459210 and C. tortuosum JF439094 from R. megalocarpum HG518627 (Fig. 1) were $16.5 \%$ and $12.1 \%$, respectively. The sequences $C$. corymbiforme KF060294 and R. megalocarpum HG518628 and
C. corymbiforme KF060295 and C. pacificum HG532011 were divergent by $12.9 \%$ and $12.0 \%$, respectively. The distance between the sequences C. globiferum FJ461836 and C. pacificum HG532013 was $5.1 \%$.

Both BI and ML analyses of the 18S-ITS-28S sequences of our Diversispora confirmed our hypothesis that this fungus is an undescribed species and indicated that its sister relative is D. clara (Fig. 1). The clades with the new Diversispora sp. and D. clara were fully supported in the BI analysis $(=1.0)$, but moderately in the ML analysis $(=72 \%$ and $83 \%$, respectively). The node connecting the two clades obtained full supports in both analyses. The divergences of the four sequences of the putative new Diversispora sp. from the four D. clara sequences (Fig. 1) ranged from 4.3 to $5.2 \%$.

Thus, based on the data discussed above, we are fully convinced that the fungus originally described as $G$. tortuosum should represent a new genus in the Diversisporaceae and the Greek diversisporoid fungus is a new species in Diversispora.

\section{Taxonomy}

\section{Erection of a new genus}

Sieverdingia Błaszk., Niezgoda \& B.T. Goto, gen. nov.

MycoBank no.: MB 832298

Type species Sieverdingia tortuosa (N.C. Schenck \& G.S. Sm.) Błaszk., Niezgoda \& B.T. Goto

Basionym Glomus tortuosum N.C. Schenck \& G.S. Sm. Mycologia 74: 83, 1982.

Specimens examined Brazil: Paraiba state, spores extracted from field-collected rhizosphere soils of T. roseo-alba and G. ulmifolia colonizing sand dunes of the city of Mataraca, unnumbered slides prepared by de Souza et al. (2013). USA: New Jersey, spores extracted from a trap culture inoculated with the rhizosphere soil of $A$. breviligulata growing at an unknown maritime dune site sampled by Dr. M. Tadych, Błaszkowski J., (slides no.) 3027-3029 (DEPSE); Oregon State University, type material (OSC\#40251) used to describe the fungus by Schenck and Smith (1982).

Etymology Sieverdingia, in honour of Dr. Ewald Sieverding, Institute for Plant Production and Agroecology in the Tropics and Subtropics, University of Hohenheim, Germany, in recognition of his important contribution to taxonomy and ecology of arbuscular mycorrhizal fungi.

Diagnosis Differs from other genera of the Diversisporaceae in producing glomoid-like spores individually covered with a 
hyphal mantle, in having a spore wall consisting of one laminate layer and a cylindrical or slightly flared subtending hypha not inflated slightly below the spore base, as well as in having the specific sequences of the nuc rDNA ITS1: AAAATTTATATAACAAATAT and ITS2: CCTAATAT GTTATATATTATGTTTACACTTGT, ACTTGTCA TTTTAATCGATTCGTGC regions.

Genus description Producing glomoid-like glomerospores individually covered with a hyphal mantle, having a spore wall consisting of one laminate layer, and a subtending hypha that is cylindrical or slightly flared and is not inflated slightly below the spore base.

\section{Sieverdingia tortuosa (N.C. Schenck \& G.S. Sm.) Błaszk., Niezgoda \& B.T. Goto, comb. nov. (Fig. 2-h)}

MycoBank no.: MB 832299

Basionym Glomus tortuosum N.C. Schenck \& G.S. Sm. Mycologia 74: 83. 1982.

Synonyms Corymbiglomus tortuosum (N.C. Schenck \& G.S. Sm.) Błaszk. \& Chwat. Acta Mycol. 48(1):99. 2013.

Etymology Latin, tortuosum (= winding), referring to the winding pattern of hyphae in the mantle covering spores of the fungus.

Description Glomerospores formed singly or in loose clusters in soil (Fig. 2, b). Spores pale yellow (4A3) to light yellow (4A4), globose to subglobose, (140-)180(-240) $\mu \mathrm{m}$ diam., sometimes ovoid, $140-170 \times 180-240 \mu \mathrm{m}$, with one subtending hypha; most mature spores, whether single or arranged in clusters, are surrounded individually by a hyphal mantle (Fig. 2a-h). Clusters globose, 280-620 $\mu \mathrm{m}$ diam., to irregular, 140-280 × 430-640 $\mu \mathrm{m}$, with 2-6 randomly distributed spores. Subcellular structure of spores consists of a single-layered spore wall that is laminate, pale yellow (4A3) to light yellow (4A4), (1.2-)2.2(-2.6) $\mu \mathrm{m}$ thick; its laminae frequently separate from each other in crushed spores (Fig. 2a-h). Subtending hypha pale yellow (4A3) to light yellow (4A4), straight or curved, cylindrical to flared, (11.5-)13.5(15.0) $\mu \mathrm{m}$ wide at the spore base (Fig. 2f), usually covered with the hyphal mantle and difficult to see. Wall of subtending hypha pale yellow (4A3) to light yellow (4A4), (1.0-)1.6(1.9) $\mu \mathrm{m}$ thick at the spore base, composed of one layer continuous with the spore wall layer (Fig. 2f). Pore gradually thins with age due to thickening of the subtending hyphal wall layer; no septum was observed in the spores examined (Fig. 2f). Hyphal mantle 8-22 $\mu$ m thick, composed of tightly interwoven, straight and branched, septate, hyaline to yellowish white (4A2), 2.7-7.8 $\mu \mathrm{m}$ wide hyphae, with walls $0.5-$
$1.0 \mu \mathrm{m}$ thick (Fig. 2-e, g, h), probably developing from the region of their subtending hypha. Mantle hyphae and spores not staining in Melzer's reagent. Juvenile and young spores frequently with no hyphal mantle (Fig. 2f). Germination through subtending hypha.

Mycorrhizal associations In the field, $S$. tortuosa probably lived in symbiosis with A. breviligulata, Glycine $\max$ (L.) Merr., Ixeris repens (L.) A. Gray, Uniola paniculata L., as well as with different other plant species (Schenck and Smith 1982; Blaschke 1991; Koske 1987; Cabello 2001; Oehl et al. 2003; Gai et al. 2006; Schalamuk et al. 2006; Wang et al. 2008; Goto et al. 2010; Błaszkowski 2012; de Souza et al. 2013; Srindhar and Beena 2012; Yamato et al. 2012; Jobim et al. 2016), although it was confirmed molecularly only with regard to I. repens (Yamato et al. 2012). In single-species cultures, $S$. tortuosa formed mycorrhiza without typical arbuscules and vesicles in roots of Paspalum secundatum (Walt.) Kuntze (Schenck and Smith 1982).

Distribution and habitat Sieverdingia tortuosa was originally identified associated with roots of $G$. max cultivated at the Agricultural Research Center, Live Oak, Florida, USA (Schenck and Smith 1982). Later, spores of this species were found in different dune sites of the USA (Koske 1987; Błaszkowski 2012), Brazil (de Souza et al. 2013), India and Japan (Srindhar and Beena 2012), and different cultivated and non-dune uncultivated soils of Argentina (Cabello 2001; Schalamuk et al. 2006), Brazil (Goto et al. 2010; Jobim et al. 2016), Switzerland (Oehl et al. 2003), Germany (Blaschke 1991), and China (Gai et al. 2006; Wang et al. 2008).

BLAST queries did not show any $18 \mathrm{~S}-\mathrm{ITS}-28 \mathrm{~S}$ sequence of identity at the species level $(\geq 97 \%)$ to the S. tortuosa $18 \mathrm{~S}-$ ITS-28S sequences used in our analyses (Fig. 1). Instead, when the query was the $S$. tortuosa partial $28 \mathrm{~S}$ sequence FJ461850 used by us, BLAST showed 10 environmental partial 28S sequences, whose identity to the FJ461850 sequence ranged from 97.45 to $98.87 \%$. The sequences represented "uncultured Diversispora" associated with I. repens growing in saline coastal beach soils in Japan (Yamato et al. 2012).

\section{Emendation of the genus Corymbiglomus Błaszk. \& Chwat emend. Błaszk. Niezgoda \& B.T. Goto}

MycoBank no.: MB 564566

Genus description Forming glomoid-like glomerospores individually covered with a hyphal mantle consisting of nonbranched or branched hyphae with or without terminal vesiculate swellings or naked spores (without a hyphal mantle). Spores occurring singly or in clusters in soil. Clusters with several spores connected by interwoven hyphae of their 


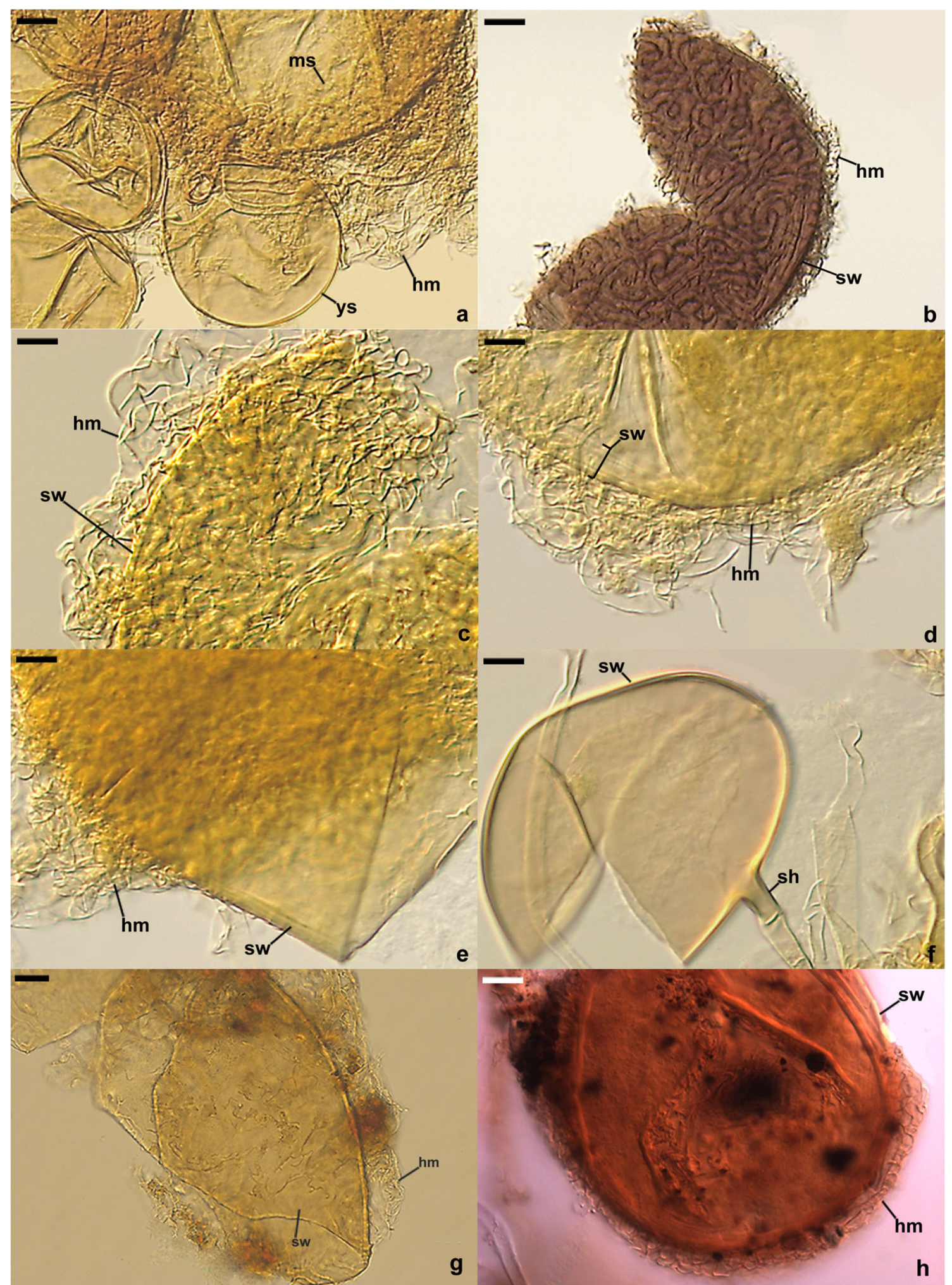

Fig. 2 Sieverdingia tortuosa. a Cluster with a mature spore (ms) covered with a hyphal mantle (hm) and young, naked (without a mantle) spores. b-e, g Spores individually covered with a hyphal mantle $(\mathrm{hm})$; note the single-layered, laminate spore wall (sw), whose laminae clearly separated from each other in d. f Spore wall (sw) and subtending hypha (sh) of a young, naked spore. a-f Spores from a trap culture inoculated with the

rhizosphere soil of A. arenaria growing in USA sand dunes. $\mathbf{g}$ Spore from sand dunes of Brazil. $\mathbf{h}$ Spore from type material (OSC \#40251). b, c, g, h Spores in PVLG. a, d, e, $\mathbf{f}$ Spores in PVLG+Melzer's reagent. $\mathbf{a}-\mathbf{h}$ Differential interference microscopy. Scale bars: $\mathbf{a}, \mathbf{b}=20 \mu \mathrm{m}, \mathbf{c}-\mathbf{h}=$ $10 \mu \mathrm{m}$ 
hyphal mantles or with two to $<20$ spores arisen at the top of sporogenous hyphae dichotomously branched from a parent hypha continuous with an extraradical mycorrhizal hypha. Subcellular structure of spores consists of one spore wall containing three or four layers, of which the innermost layer is laminate, flexible to semi-flexible, hyaline, relatively thick, frequently readily separating from the penultimate spore wall layer above the spore base, but it is associated with the penultimate spore wall layer at the spore base and with the inner surface of the spore subtending hyphal wall at the spore base or much below. Subtending hypha straight or recurved, cylindrical to funnel-shaped or constricted. Subtending hyphal wall continuous with and coloured similarly to or slightly lighter than the spore wall. Pore occluded by (i) ingrowth of the innermost colourless spore wall layer (layer 3 or 4), (ii) a septum continuous with the innermost laminae of the coloured laminate spore wall layer 2, (iii) both the structures, (iv) a septum continuous with the innermost laminae of spore wall layer 2 and adherent spore wall layer 3, and (v) occasionally by thickening of spore wall layer 2 ; the pore sometimes seems to be open (Medina et al. 2014). Germination by a germ tube penetrating through the lumen of the subtending hypha and/or the spore wall (see our Fig. 3h; Medina et al. 2014).

Type species Corymbiglomus corymbiforme (Błaszk.) Błaszk. \& Chwat. Glomeromycota 274. 2012.

Other species Corymbiglomus globiferum (Koske \& Walker) Błaszk \& Chwat.

Basionym Glomus globiferum Koske \& Walker. Mycotaxon 26: 133.1986.

Corymbiglomus pacificum Oehl, J. Medina, P. Cornejo, Sánchez-Castro, G.A. Silva \& Palenz. Mycotaxon 127: 176. 2014.

\section{Emendations of Corymbiglomus corymbiforme, C. globiferum, and C. pacificum}

\section{Corymbiglomus corymbiforme (Błaszk.) Błaszk. \& Chwat emend. Błaszk. Niezgoda \& B.T. Goto (Figs. 3-h and 4a, b)}

MycoBank no.: MB 564567

Glomeromycota (Kraków): 274. 2012.

Basionym Glomus corymbiforme Błaszk. Mycologia 87(5): 732. 1995.

Etymology Latin, corymbiforme, referring to the clustered, corymbiform organization of spores in clusters of the fungus.

Specimens examined Poland: Glomerospores extracted from: (i) field-collected rhizosphere soils of A. arenaria, 6.10.1993,
Błaszkowski J., (slides no.) 2022 (holotype, DEPSE), Btaszkowski J., 2023-2025 (isotypes, DEPSE), 1.10.1991, Błaszkowski J., 2004-2010 (DEPSE), 22.09.1992, Błaszkowski J., 2011-2015 (DEPSE); Petasites spurius (Retz.) Rchb., 6.10.1993, Btaszkowski J., 2019 (DEPSE); and Hieracium umbellatum L., 6.10.1993, Btaszkowski J., 2020-2021 (DEPSE); and (ii) single-species cultures inoculated with the rhizosphere soil of A. arenaria, 5.11.2018, Btaszkowski J., 3660-3667 (DEPSE). All the plant species colonized dunes of the Baltic Sea located near the city of Świnoujście (53 $55^{\circ} 03^{\prime \prime} \mathrm{N} 14^{\circ} 17^{\prime} 39^{\prime \prime}$ 'E) and were sampled by J. Błaszkowski.

Diagnosis Differs from other species of Corymbiglomus in the formation of glomerospores mainly in corymbiform clusters (rarely singly), in which spores are individually covered with a hyphal mantle produced by dichotomously branched hyphae grown from spore wall layer 1 and in the nucleotide composition of sequences of the 18S-ITS-28S nuc rDNA region.

Description Glomerospores occurring in corymbiform clusters when formed from branched sporophores (Fig. 3, b), rarely singly in soil when produced from straight sporophores. Clusters globose to subglobose, (180-)336(-490) $\mu \mathrm{m}$ diam., sometimes ovoid, $180-350 \times 210-500 \mu \mathrm{m}$, composed of 2 13 (av. 6) spores enveloped individually by a hyphal mantle (Fig. 3, b, e). Spores pastel yellow (3A4) to orange (6A8), globose to subglobose, (50-)142(-220) $\mu \mathrm{m}$ diam., sometimes ovoid or pyriform, $110-125 \times 120-200 \mu \mathrm{m}$, with one subtending hypha (Fig. 3-h). Subcellular structure of spores of one wall with three permanent layers. Layer 1 uniform (not divided into visible sublayers), semi-rigid, smooth or slightly roughened, hyaline to deep yellow (4A8), (0.7-)1.1(-1.7) $\mu \mathrm{m}$ thick, closely attached to layer 2 (Fig. 3c-h). Layer 2 laminate, pastel yellow (3A4) to orange (6A8), (3.9-)7.0(-10.0) $\mu \mathrm{m}$ thick (Fig. 3c-h). Layer 3 laminate, semi-flexible, hyaline, $(0.5-) 3.4(-5.8) \mu \mathrm{m}$ thick, usually tightly adherent to layer 2 in young and field-collected, even vigorously crushed, spores, but frequently separating from layer 2 in moderately crushed young and older spores extracted from pot cultures (Fig. 3ch), usually with a small protrusion invaginated in the lumen of the subtending hypha (Fig. 3d, f, h). Subtending hypha cream (4A3) to deep orange (5A8), straight or recurvate, flared, sometimes cylindrical or constricted at the spore base, $(9.8-) 21.0(-31.1) \mu \mathrm{m}$ wide at the spore base (Fig. 3e-h). Wall of subtending hypha cream (4A3) to deep orange (5A8), (2.2-)6.5(-13.7) $\mu \mathrm{m}$ thick, composed of three layers continuous with spore wall layers 1-3; subtending hyphal wall layer 3 present only at or far below the spore base (Fig. 3d-h). Pore occluded by (i) ingrowth of spore wall layer 3; (ii) a septum, (4.5-)9.6(-15.3) $\mu \mathrm{m}$ wide and (1.5-)1.7(-2.0) $\mu \mathrm{m}$ thick, continuous with the innermost lamina of spore wall layer 2; (iii) both the structures; and occasionally by (iv) 

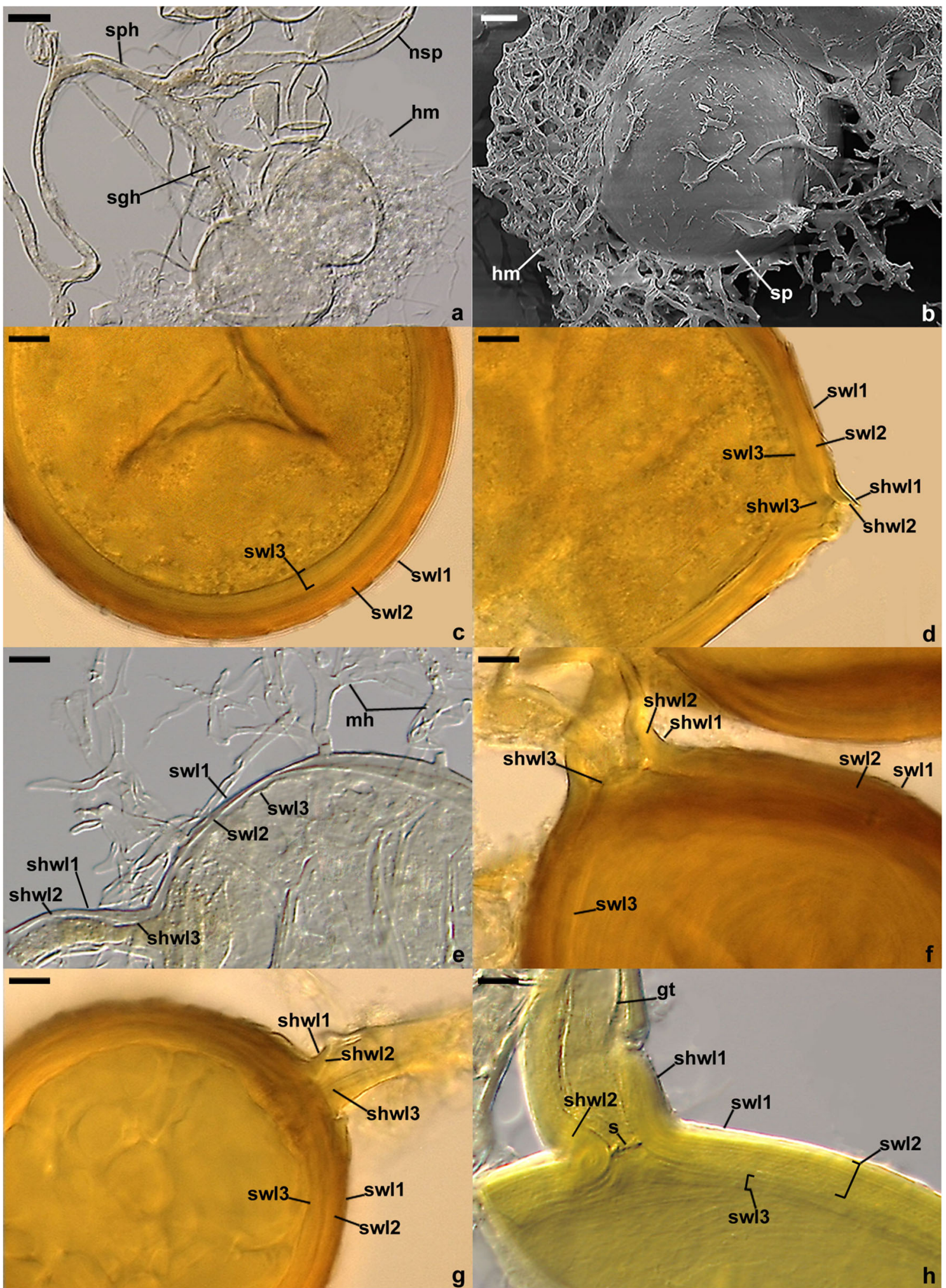

Fig. 3 Corymbiglomus corymbiforme. a Cluster with young naked spores (nsp) and spores covered with hyphal mantle (hm); spores arisen terminally on sporogenous hyphae (sgh) dichotomously branched from sporophore (sph). b Spore (sp) with hyphal mantle (hm). c Spore wall layers (swl) 1-3; note the thick, colourless swl3. d, f-h Spore wall layers (swl) 1-3 continuous with subtending hyphal wall layers (shwl) 1-3; note the subtending hyphal pore closed by the invaginated swl 3 in $\mathbf{d}, \mathbf{f}$ and $\mathbf{h}$ and both swl3 and a septum (s) connecting the inner surfaces of the laminate

swl2 in $\mathbf{~}$; in $\mathbf{g}$, the pore is open; a germ tube (gt) in the subtending hyphal lumen is visible in $\mathbf{h}$. e Subtending hyphal wall layers (shwl) 1-3 continuous with spore wall layers (swl) 1-3 and mantle hyphae (mh) grown from swl1; note shwl3 that started developing far below the spore base. a, $\mathbf{c}, \mathbf{e}-\mathbf{h}$ Spores in PVLG. d Spore in PVLG+Melzer's reagent. a, $\mathbf{c}-\mathbf{h}$ Differential interference microscopy. b Scanning electron microscopy. Scale bars: $\mathbf{a}=20 \mu \mathrm{m}, \mathbf{b}-\mathbf{h}=10 \mu \mathrm{m}$ 
thickening of spore wall layer 2 (Fig. 3d, f, h), rarely open (Fig. 3e). Mantle (20.0-)47.5(-90.0) $\mu \mathrm{m}$ thick, consisting of a network of hyphae branching dichotomously three to four times at more or less right angles; hyphae thin-walled, hyaline to yellowish white (3A2), septate; length and diameter of branches diminishing with each successive dichotomy; initial hypha (9.8-)17.7(-27.2) $\mu \mathrm{m}$ long, (4.2-)4.9(-6.9) $\mu \mathrm{m}$ wide; developing from spore wall layer 1 ; final branch (13.5-)19.4(-25.0) $\mu \mathrm{m}$ long, (1.2-)1.8(-2.9) $\mu \mathrm{m}$ wide; distance between septa (14.5-)25.7(-31.4) $\mu \mathrm{m}$; mantle frequently absent in mature spores (Fig. 3, b, e). Sporophore coenocytic to sparsely septate, hyaline to yellow (5A6), $(10.3-) 14.7(-17.5) \mu \mathrm{m}$ wide, with a wall $(1.5-) 1.6(-1.7) \mu \mathrm{m}$ thick, usually with two to three main monopodial branches, rarely straight; main branches frequently with one to ten (av. 4) monopodial second branches sometimes branched monopodially one or two times; main, second, and third branches slanted at $30-45^{\circ}$ towards their parent hyphae; straight and branched sporophores bearing spores by swelling hyphal tips (Fig. 3). Mantle and spores not reacting in Melzer's reagent. Germination by a germ tube penetrating through the lumen of the subtending hypha (Fig. 3 h).

Mycorrhizal associations In the field, $C$. corymbiforme was probably associated with roots of A. arenaria, Artemisia campestris L., Corynephorus canescens (L.) P. Beauv., Festuca polesica Zapał., Galium mollugo L., Helichrysum arenarium (L.) Moench, Hieracium pilosella L., H. umbellatum, Petasites spurius, Potentilla anserina L., Rosa rugosa Thunb., Solidago virgaurea L., and Viola tricolor L. (Błaszkowski 1995, unpubl. data; Tadych and Błaszkowski 2000; Błaszkowski et al. 2002a, 2002b; Błaszkowski and Czerniawska 2006). However, no molecular analysis was performed on roots of these plant species to confirm this supposition. In single-species cultures, $C$. corymbiforme formed mycorrhiza with arbuscules and intra- and extraradical hyphae staining moderately to intensively [pale violet (17A3) to violet (17B7)] in $0.1 \%$ Trypan blue (Fig. 4a, b).

Distribution and habitat Glomerospores of $C$. corymbiforme were originally extracted from maritime dunes located near Świnoujście in north-western Poland (Błaszkowski 1995). Other records of this species also originate mainly from dune sites: the Słowiński National Park (Tadych and Błaszkowski 2000) and the Mierzeja Wiślana spit (Błaszkowski et al. 2002a), both belonging to Poland, dunes of the Mediterranean Sea located near Karabucak-Tuzla (Turkey), Tel-Aviv (Israel), Majorca (Spain; Błaszkowski and Czerniawska 2006; Błaszkowski, unpubl. data), and inland dunes of the Pustynia Błedowska desert (Poland, Błaszkowski et al. 2002b). In addition, $C$. corymbiforme was found in semiarid open sandy grasslands of Hungary (Takacs and Bratek 2006; Błaszkowski, unpubl. data).
Comparisons of the 18S-ITS-28S sequences of C. corymbiforme with sequences deposited in public databases did not show any record of this species.

\section{Corymbiglomus globiferum (Koske \& C. Walker) Błaszk. \& Chwat emend. Błaszk. Niezgoda \& B.T. Goto (Fig. 4c-f)}

MycoBank no.: MB 622179

Acta Mycol. 48(1): 99. 2013.

Basionym Glomus globiferum Koske \& Walker. Mycotaxon 26: 133. 1986.

Etymology Latin, globiferum (= "sphere bearing"), referring to the spherical or near-spherical vesiculate swellings produced by mantle hyphae on the outside of spores (Koske and Walker 1986).

Specimens examined Brazil: Glomerospores extracted from trap cultures inoculated with the rhizosphere soils of two sand dune plant species: $C$. crassipes growing near the city of Galinhos (UFRN Fungos-3166) and E. polyphyla growing in the RDSE Ponta do Tubarão (UFRN-Fungos-3167), both located in the Rio Grande do Norte State.

Diagnosis Differs from other species of Corymbiglomus in the formation of single glomerospores individually covered with a hyphal mantle containing vesiculate swellings, whose hyphae grow from spore wall layer 1 and the subtending hyphal wall, as well as in the nucleotide composition of sequences of the 18S-ITS-28S nuc rDNA region.

Description Glomerospores hypogeous, formed singly, occasionally in clusters with two to several spores connected by interwoven hyphae of a mantle individually covering each spore. Spores dark orange (5A8) to brownish red (9C8), globose to subglobose, (160-)249(-320) $\mu \mathrm{m}$ diam., with one subtending hypha (Fig. 4c-f). Subcellular structure of spores consists of one wall composed of three layers. Layer 1 uniform (not divided into visible sublayers), semi-permanent, semi-rigid, smooth or slightly roughened, hyaline to light orange (5A4), $(1.2-) 1.7(-2.3) \mu \mathrm{m}$ thick, closely attached to layer 2, occasionally slightly deteriorated in older spores (Fig. 4d-f). Layer 2 laminate, permanent, smooth, dark orange (5A8) to brownish red (9C8), (10.0-)17.1(-23.8) $\mu \mathrm{m}$ thick (Fig. 4d-f); the thickness is frequently higher in crushed spores due to the plastic properties of this layer. Layer 3 laminate, permanent, semi-flexible, hyaline, $(2.0-) 2.9(-4.8) \mu \mathrm{m}$ thick, usually tightly adherent to layer 2, usually with a small protrusion invaginated in the lumen of the subtending hypha (Fig. 4d-f). Subtending hypha pale yellow (4A3) to reddish orange (7A6), straight or recurvate, cylindrical or slightly constricted at the spore base, rarely funnel-shaped, 15.0-27.0 $\mu \mathrm{m}$ wide at the spore base 

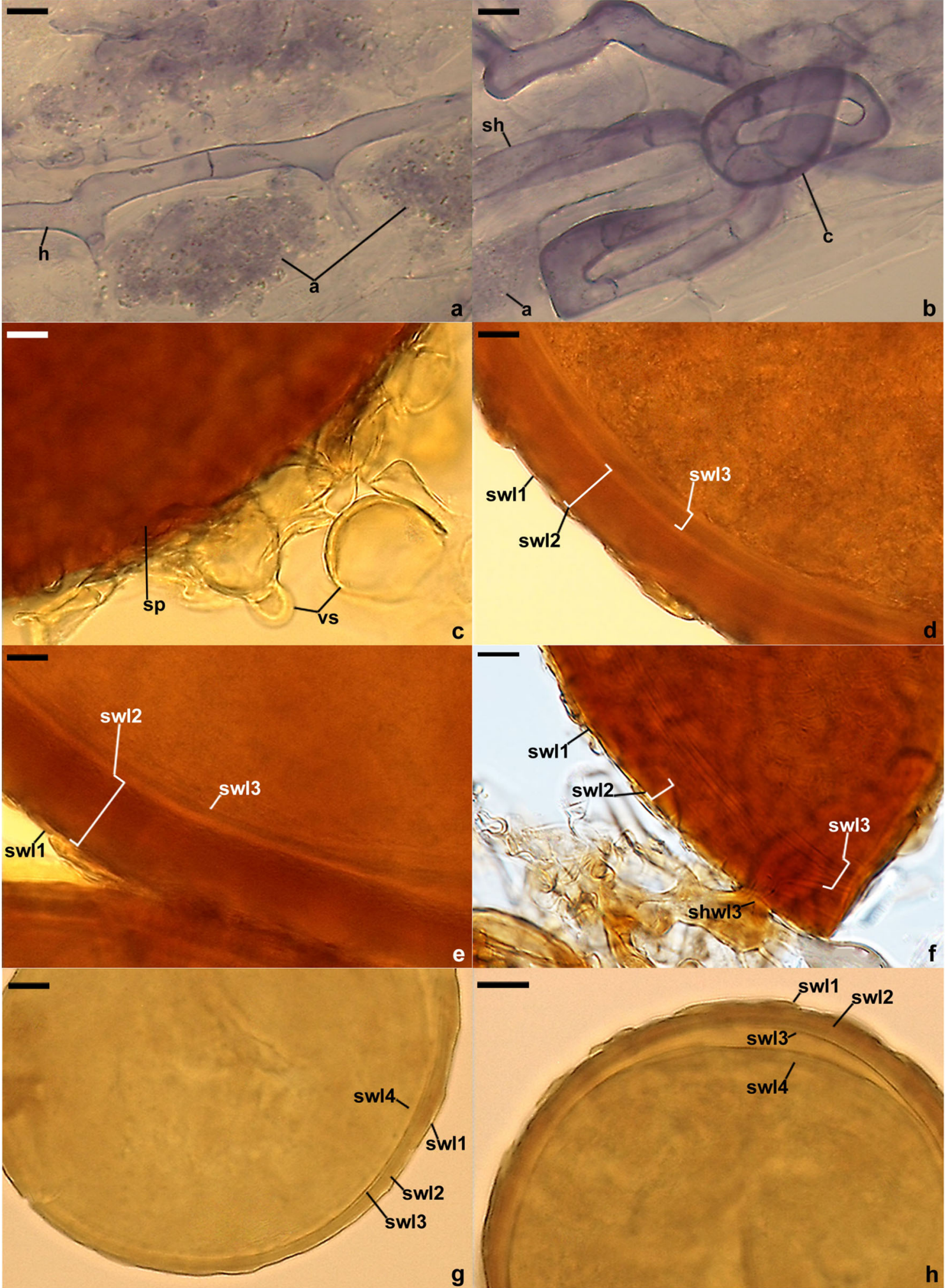

e

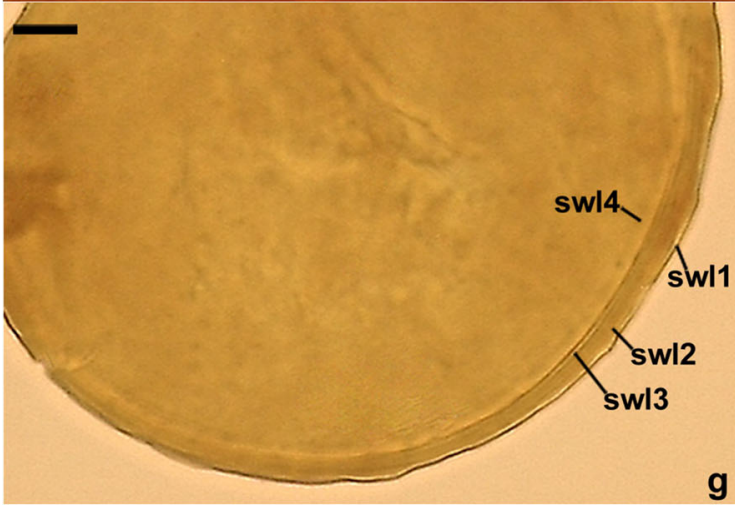

Fig. 4 a, b Corymbiglomus corymbiforme. a Arbuscules (a) and intraradical hypha (h). b Arbuscule (a) and straight (sh) and coiled (c) intraradical hyphae. $\mathbf{c}-\mathbf{f}$ Corymbiglomus globiferum. c Spore (s) covered with a hyphal mantle with vesiculate swellings (vs). d-f Spore wall layers

1-3; note the separated sublayers of swl3 in e and f. $\mathbf{g}, \mathbf{h}$. Corymbiglomus pacificum. g, h Spore wall layers (swl) 1-4. a, b, d, f-h Spores in PVLG. c, e Spores in PVLG+Melzer's reagent. a-h Differential interference microscopy. Scale bars: $\mathbf{a}-\mathbf{h}=10 \mu \mathrm{m}$

(Fig. 4f). Wall of subtending hypha pale yellow (4A3) to reddish orange (7A6), 2.0-8.0 $\mu \mathrm{m}$ thick, composed of three layers

continuous with spore wall layers 1-3 (Fig. 4f). Pore occluded by (i) ingrowth of spore wall layer 3, (ii) a septum continuous 
with the innermost lamina of spore wall layer 2, and (iii) occasionally by a granular plug. Germination by a germ tube penetrating through the lumen of the subtending hypha. Mantle 5$47 \mu \mathrm{m}$ thick, consisting of loosely or tightly interwoven hyphae bearing numerous terminal or intercalary vesiculate swellings (Fig. 4c); hyphae coenocytic or sparsely septate, hyaline to pale yellow to yellow-brown, 5.0-50.0 $\mu \mathrm{m}$ wide, with walls (1.0-)1.5(-1.8) $\mu \mathrm{m}$ thick; swellings hyaline to pale yellowbrown, globose to ovoid, $12-75 \mu \mathrm{m}$ diam., with a singlelayered wall, 0.8-2.0 $\mu \mathrm{m}$ thick. Mantle and spores not reacting in Melzer's reagent.

Mycorrhizal associations In the field, C. globiferum probably formed mycorrhiza with A. breviligulata and U. paniculata (Koske and Walker 1986; Sylvia 1986; Sylvia and Will 1988; Wu and Sylvia 1993), as well as with C. crassipes and E. polyphylla (pers. observ.), although no molecular analysis was performed on roots of these plant species to confirm this supposition. BLAST searches indicated that, of the C. globiferum sequences used in our analyses (Fig. 1), only the partial 28S sequence FJ461836 showed 97.32-97.74\% identity to two partial 28S sequences (AB670091, AB670092) obtained from DNA extracted from roots of I. repens (Yamato et al. 2012). However, the association of C. globiferum with $I$. repens was not confirmed when our 18S-ITS-28S sequences were used in the searches. In singlespecies cultures, C. globiferum formed mycorrhiza with $U$. paniculata, but the level of colonization was low (Sylvia and Burks 1988).

Distribution and habitat Corymbiglomus globiferum was originally characterized from glomerospores found in sand dunes at Cape May, New Jersey (Koske and Walker 1986). Sylvia (1986), Sylvia and Will (1988), and Wu and Sylvia (1993) extracted spores of this species from costal sand dunes in Florida. The specimens of this fungus used in our analyses originated from saline and no saline sand dunes located at the city of Galinhos $\left(78^{\circ} 02^{\prime} \mathrm{S}, 94^{\circ} 37^{\prime} \mathrm{W}\right)$ and in the RDSE Ponta do Tubarão ( $5^{\circ} 5^{\prime} 3.55^{\prime \prime} \mathrm{S}, 36^{\circ} 28^{\prime} 19.13^{\prime \prime} \mathrm{W}$ ), Brazil. In addition, Yamato et al. (2012) concluded from molecular environmental analyses that $C$. globiferum occurred in roots of I. repens sampled near the Tottrii sand dunes in Japan.

\section{Corymbiglomus pacificum Oehl, J. Medina, P. Cornejo, Sánchez-Castro, G.A. Silva \& Palenz. emend. Błaszk. Niezgoda \& B.T. Goto (Figs. $4 \mathrm{~g}, \mathrm{~h}$ and $5 \mathrm{a}-\mathrm{h}$ ).}

MycoBank no.: MB 805601
Mycotaxon 127: 176. 2014.

Etymology Latin, pacificum, referring to the Pacific Ocean, which is adjacent to the isolation site (Medina et al. 2014).
Specimens examined Slides with glomerospores permanently mounted in PVLG and PVLG+Melzer's reagent loaned from the mycological herbarium of ETH Zurich $(Z+Z T$, Switzerland): ZT Myc 49005-holotype (two slides), ZT Myc 49006-isotypes (six slides).

Diagnosis Differs from other species of Corymbiglomus in the formation of single glomerospores not covered with a hyphal mantle, in having spores with a four-layered spore wall, and in the nucleotide composition of sequences of the $28 \mathrm{~S}$ nuc rDNA region.

Description Glomerospores hypogeous, formed singly. Spores bright yellow to dark yellow to rarely brownish yellow, globose to subglobose to rarely ellipsoid to irregular, (85-)95-130($135) \times(75-) 85-125(-131) \mu \mathrm{m}$ diam., with one subtending hypha (Figs. 4g, h and 5a-h). Subcellular structure of spores consists of one spore wall with four layers. Layer 1 evanescent to semi-permanent, subhyaline to light yellow, 0.6-1.2 $\mu \mathrm{m}$ thick, usually tightly adherent to layer 2 (Figs. $4 \mathrm{~g}, \mathrm{~h}$ and $5 \mathrm{a}-$ d). Layer 2 permanent, laminate, smooth, bright yellow to dark yellow to brownish dark yellow, 1.8-3.5(-4.5) $\mu \mathrm{m}$ thick (Figs. 4g, h and 5a-d). Layer 3 permanent, uniform (not divided into visible sublayers), hyaline to dull yellow (4B3), 0.4 $0.7 \mu \mathrm{m}$ thick, usually separating from layer 3 only in vigorously crushed spores, and, therefore, difficult to see (Figs. $4 \mathrm{~g}$, $\mathrm{h}$ and 5a). Layer 4 permanent, laminate, hyaline, $(2.3-) 3.4(-4.7) \mu \mathrm{m}$ thick, usually with a small protrusion invaginated in the lumen of the subtending hypha (Fig. $4 \mathrm{~g}$, h and 5a-d). In Melzer's reagent, only spore wall layer 4 may stain light yellow to bright dark yellow. Subtending hypha usually lighter than spores, light yellow (4A4) to greyish orange (5B5), straight, rarely recurvate, cylindrical, sometimes constricted at the spore base, 7.0 $12.0 \mu \mathrm{m}$ wide at the spore base (Fig. 5c, d). Wall of subtending hypha light yellow (4A4) to greyish orange (5B5), 2.4-5.7 $\mu \mathrm{m}$ thick at the spore base, composed of four layers continuous with spore wall layers 1-4 at the spore base, and two layers continuous with spore wall layers 1 and 2 below the spore base (Fig. 5c, d). Pore usually occluded by a straight or slightly curved septum, (3.2-)3.7(-4.4) $\mu \mathrm{m}$ wide and ca. $2.0 \mu \mathrm{m}$ thick, continuous with spore wall layers 2-4 (Fig. 5d), rarely open. Germination by a germ tube growing from spore wall layer 4 and penetrating through the other spore wall layers.

Mycorrhizal associations In the field, $C$. pacificum was associated with roots of $A$. arenaria (Medina et al. 2014). Attempts to propagate this species in culture failed. Thus, morphological features of $C$. pacificum mycorrhizal structures remain unknown.

Distribution and habitat So far, C. pacificum was physically identified only among roots of $A$. arenaria growing at the mouth of Lake Budi, a saline ecosystem periodically connecting with 

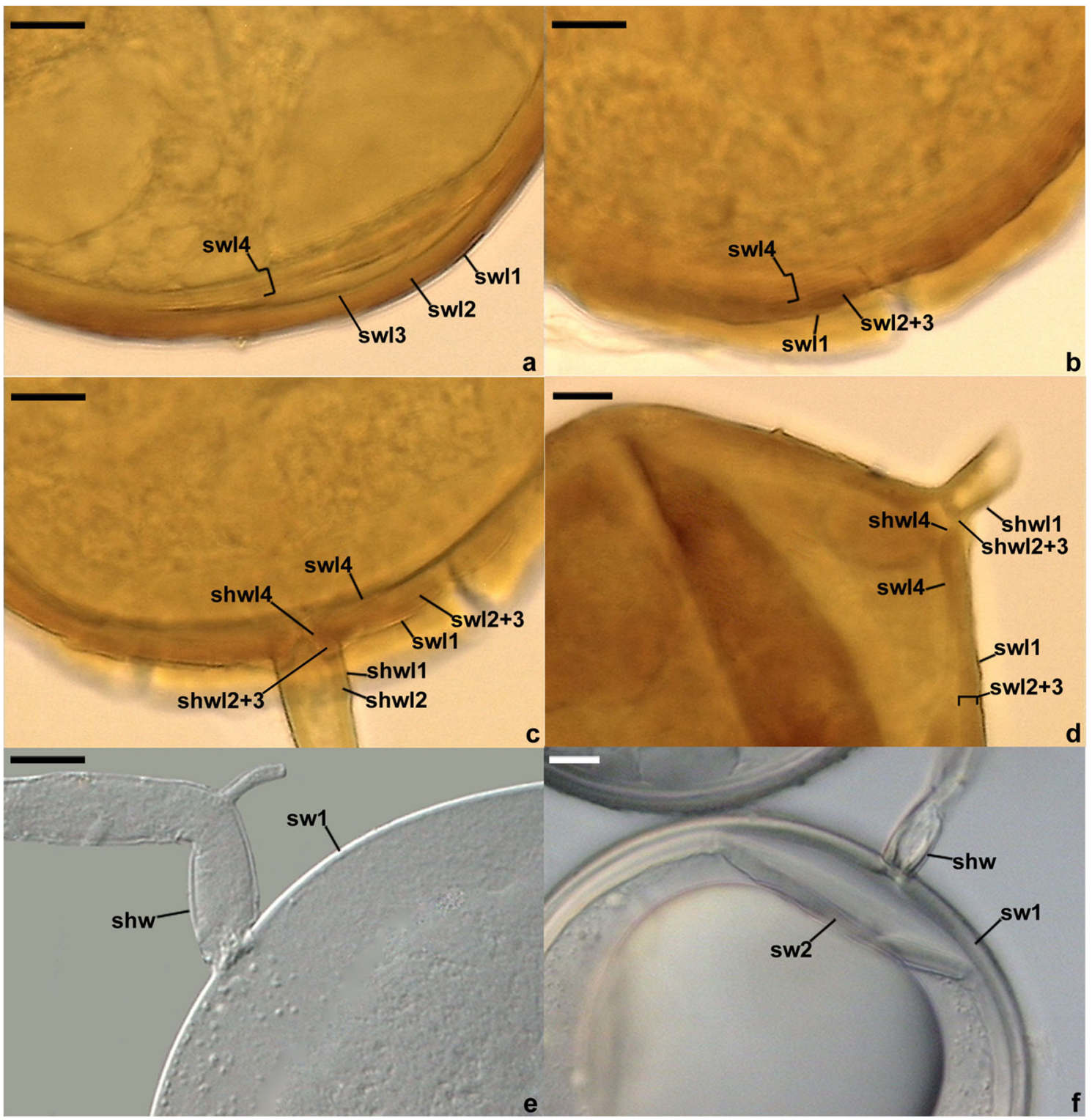

Fig. 5 a-d Corymbiglomus pacificum. a, b Spore wall layers (swl) 1-4; note the laminae of the laminate swl4. c, d Spore wall layers (swl) 1-4 continuous with subtending hyphal wall layers (shwl) $1-4$; note shwl4 is present only at the spore base; shwl3 probably is present, but is invisible because it is very thin and of colour similar to that of shwl2. e, f Pacispora scintillans. e Subtending hyphal wall (shw) continuous with spore wall 1

the Pacific Ocean, located near the municipality Puerto Saavedra in La Araucanía Region (southern Chile; Medina et al. 2014). There are no available molecular data that would indicate that C. pacificum also occurs in other sites of the world.

\section{Description of a new species}

\section{Diversispora peloponnesiaca Błaszk., B.T. Goto, Orfanoudakis \& Niezgoda sp. nov. (Fig. 6a-h).}

MycoBank no.: MB 832300 (sw1) of a juvenile specimen; note the single-walled subcellular structure of the spore. f Subtending hyphal wall (shw) continuous with spore wall 1 (sw1) having no physical contact with spore wall 2 (sw2) of a mature specimen. a-f Spores in PVLG. a-f Differential interference microscopy. Scale bars: $\mathbf{a}-\mathbf{f}=10 \mu \mathrm{m}$

Etymology Latin, peloponnesiaca, referring to the Peloponnese peninsula, where this species was originally found.

Specimens examined Poland: Glomerospores from a singlespecies culture established from spores extracted from a trap culture inoculated with the rhizosphere soil of $A$. arenaria that colonized Mediterranean Sea dunes of the beach Voidokoilia ( $36^{\circ} 57^{\prime} 46^{\prime \prime} \mathrm{N} 21^{\circ} 39^{\prime} 45^{\prime \prime}$ E) located on the Peloponnese peninsula, Greece. The field soil sample was collected by Dr. Dimitris Arrianas on July 18, 2012. Holotype. Slide with spores no. ZT Myc 60277 (Z+ZT), isotypes: slides with spores no. 3650-3659 (DEPSE). 
Diagnosis Differs from other Diversispora spp. in producing glomerospores that are darkest in colour and in the nucleotide composition of sequences of the 18S-ITS-28S nuc rDNA region.

Description Glomerospores formed singly in soil (Fig. 6a). Spores arise blastically at the tip of sporogenous hyphae. Spores orange (5B8) to reddish brown (8E8) when mature, light yellow (3A5) to reddish yellow (4A7) when young; usually ovoid; $108-142 \times 127-171 \mu \mathrm{m}$; less often globose to subglobose; (113-)139(-163) $\mu \mathrm{m}$ diam.; with one subtending hypha (Fig. 6a-f). Spore wall composed of three permanent layers. Layer 1, forming the spore surface, semi-flexible, smooth, deep yellow (4A8) to yellowish brown (5D8) in mature spores, hyaline in young spores, $(1.3-) 1.8(-2.3) \mu \mathrm{m}$ thick (Fig. 6b-f, h). Layer 2 laminate, semi-flexible, orange (5B8) to reddish brown (8E8) in mature spores, light yellow (3A5) to reddish yellow (4A7) in young spores, (6.3-)8.4(-11.3) $\mu \mathrm{m}$ thick (Fig. 6b-f, h). Layer 3 uniform (not divided into visible sublayers), semi-flexible, hyaline to greyish yellow (4C3), $(1.0-) 1.1(-1.3) \mu \mathrm{m}$ thick, usually tightly adherent to the lower surface of layer 2, occasionally separating from this layer in vigorously crushed spores (Fig. 6b-f, h). Layers 1-3 not staining in Melzer's reagent. Subtending hypha hyaline to greyish yellow (4B3); straight or recurved, cylindrical, rarely slightly constricted at the spore base; $(9.0-) 11.8(-14.5) \mu \mathrm{m}$ wide at the spore base (Fig. 6g, h); frequently breaking in crushed spores. Wall of subtending hypha hyaline to greyish yellow (4B3); $(1.8-) 2.1(-2.3) \mu \mathrm{m}$ thick at the spore base; consisting of one layer continuous with spore wall layer 1 (Fig. $6 \mathrm{~g}$, g). Pore (6.3-)8.9(-10.3) $\mu \mathrm{m}$ wide at the spore base, occluded by either a straight or slightly curved septum, 1.5-2.0 $\mu \mathrm{m}$ thick, connecting the inner surfaces of the subtending hyphal wall at or up to $2.5 \mu \mathrm{m}$ below the spore base (Fig. $6 \mathrm{~g}$ ), or a curved septum continuous with spore wall layer 3 (Fig. 6h). Germination unknown.

Mycorrhizal associations In the field, D. peloponnesiaca probably lived in symbiosis with $A$. arenaria, although no molecular analysis was performed on roots of this plant species to confirm this hypothesis. In single-species cultures with $P$. lanceolata as the host plant, $D$. peloponnesiaca formed mycorrhiza with arbuscules, vesicles, and intraradical and extraradical hyphae that stained violet white (16A2) to dark violet (16F8) in $0.1 \%$ Trypan blue.

Distribution and habitat To date, D. peloponnesiaca was physically found in only one trap culture representing dunes of the Mediterranean beach Voidokoilia ( $36^{\circ} 57^{\prime} 46^{\prime \prime} \mathrm{N} 21^{\circ} 39^{\prime}$ $45^{\prime \prime}$ E) located on the Peloponnese peninsula, Greece. BLAST queries did not show any sequence of $\geq 97 \%$ identity to the $18 \mathrm{~S}-I T S-28 \mathrm{~S}$ sequences of $D$. peloponneseae. The identity of all listed sequences was $<95.73 \%$.

\section{Discussion}

The molecular phylogenetic analyses discussed above fully confirmed our hypothesis that the fungus originally described as G. tortuosum (Schenck and Smith 1982) and later accommodated in the genus Corymbiglomus (Błaszkowski and Chwat 2013) should be transferred to a new genus, here described as Sieverdingia, in the family Diversisporaceae. Importantly, the transfer removed inconsistencies between the morphological features of spores of $C$. corymbiforme, C. globiferum, and C. pacificum versus those of $S$. tortuosa (Schenck and Smith 1982; Koske and Walker 1986; Błaszkowski 2012; Medina et al. 2014; http://fungi.invam. wvu.edu/the-fungi/classification/diversisporaceae/ diversispora/tortuosum.html; http://fungi.invam.wvu.edu/thefungi/classification/diversisporaceae/diversispora/globiferum. html). Finally, the analyses confirmed our supposition, resulting from morphological observations, that the diversisporoid spore-producing fungus that we found and grew in cultures is a new species in the genus Diversispora (Fig. 1).

The phylogeny of Sieverdingia was reconstructed from analyses of 18S-ITS-28S nuc rDNA sequences and partial sequences of the $28 \mathrm{~S}$ gene of the so far sole species of the new genus, S. tortuosa (Fig. 1). The nesting of the FJ461850 partial 28S sequence obtained from spores of $S$. tortuosa grown in the International Culture Collection of (Vesicular) Arbuscular Mycorrhizal Fungi (INVAM; treated as D. tortuosa) between three S. tortuosa 18S-ITS-28S sequences obtained from spores originating from China proved that the four sequences characterize one species and strongly supported the validity of the erection of Sieverdingia. The accuracy and resolution power of phylogenies generally are higher when the number of analyzed molecular sequences and the amount of information contained in these sequences are higher (Redecker et al. 2013; Stockinger et al. 2014).

Currently, the living culture from which type specimens of the fungus originally described as G. tortuosum were extracted (Schenck and Smith 1982) does not exist (http://fungi. invam.wvu.edu/the-fungi/classification/diversisporaceae/ diversispora/tortuosum.html). However, the morphology of spores of the type specimens permanently mounted on slides (B.T. Goto, pers. observ.; Fig. 2h), as well as that of spores extracted from living cultures grown by Dr. J.B. Morton in INVAM, B.T. Goto (Fig. 2g), and by J. Błaszkowski (Fig. 2af; Błaszkowski 2012; http://fungi.invam.wvu.edu/the-fungi/ classification/diversisporaceae/diversispora/tortuosum.html; http://www.zor.zut.edu.pl/Glomeromycota/) unambiguously indicates that the spores were produced by one species, $S$. tortuosa. Our $S$. tortuosa morphologically characterized above (see the section "Erection of a new genus"; Fig. 2a-h) slightly differed in only three features from $G$. tortuosum and D. tortuosa described and illustrated by Schenck and Smith 

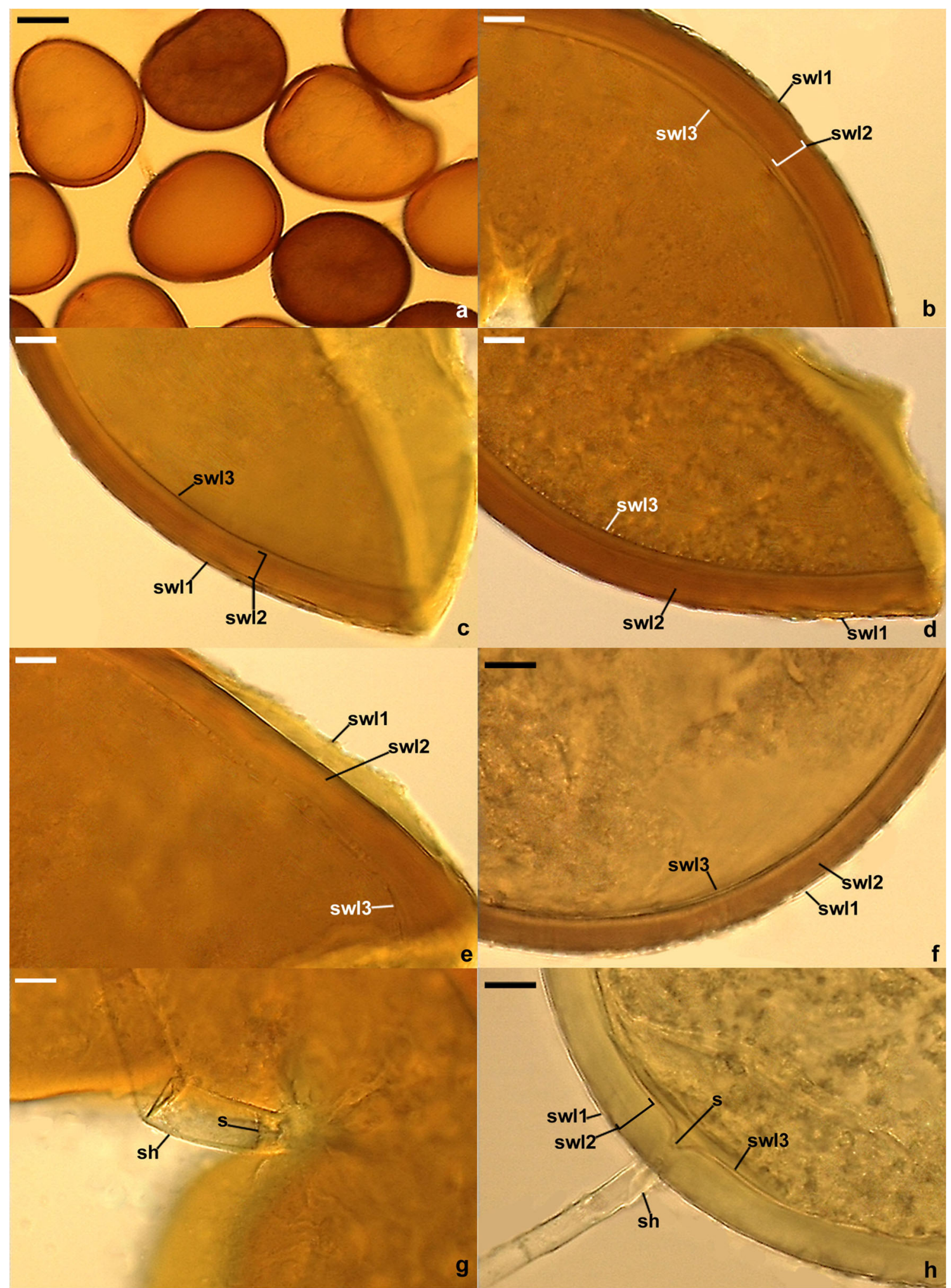

Fig. 6 a-f Diversispora peloponnesiaca. a Intact spores. b-f Spore wall layers (swl) 1-3. g A straight septum (s) connecting the inner surfaces of the subtending hyphal (sh) wall located slightly below the spore base. $\mathbf{h}$ Spore wall layers (swl) $1-3$, subtending hypha (sh), and a curved septum

(1982) and Morton (http://fungi.invam.wvu.edu/the-fungi/ classification/diversisporaceae/diversispora/tortuosum.html), (s) continuous with swl3, closing the lumen of sh. a Spores in lactic acid. $\mathbf{b}, \mathbf{c}, \mathbf{e}-\mathbf{h}$ Spores in PVLG+Melzer's reagent. $\mathbf{d}$ Spore in PVLG. $\mathbf{a}-\mathbf{h}$ Differential interference microscopy. Scale bars: $\mathbf{a}=50 \mu \mathrm{m}, \mathbf{b}-\mathbf{h}=10 \mu \mathrm{m}$

respectively. The spores were (i) slightly lighter than those defined by Schenck and Smith (1982; yellow to dull grey- 
brown) and Morton (light yellow-brown to orange brown), (ii) their spore wall was slightly thicker than $0.5-2.0 \mu \mathrm{m}$ (Schenck and Smith 1982; no data in Morton's website), and (iii) their subtending hypha was not as wide as $20-26 \mu \mathrm{m}$ (Schenck and Smith 1982), but the range of its width was similar to that given by Morton.

Morphologically, S. tortuosa is distinguished mainly by its single-layered, coloured spore wall, which is covered with a mantle consisting of straight or sinuous hyphae (Schenck and Smith 1982; Błaszkowski 2012; http://fungi.invam.wvu.edu/ the-fungi/classification/diversisporaceae/diversispora/ tortuosum.html; Fig. 2-h). The mantle hyphae are frequently interwoven with those of a spore or spores arising nearby, and therefore, S. tortuosa usually forms clusters with randomly distributed spores. Of the 15 described species of the Glomeromycota that produce glomoid or glomoid-like coloured spores with a single-layered spore wall, which do not arise radially from a central sterile hyphal plexus as spores of Sclerocystis spp., only spores of $S$. tortuosa and $G$. convolutum Gerd. \& Trappe are individually enclosed in a hyphal mantle (Gerdemann and Trappe 1974; Schenck and Smith 1982; Błaszkowski 2012). Both species are easily distinguishable from one another based on their morphology. While spores of $S$. tortuosa arise singly or in rather loose clusters (Fig. $2 \mathrm{a}-\mathrm{h}$ ), those of $G$. convolutum are formed in compact glomerocarps (Gerdemann and Trappe 1974). The laminate spore wall layer of the former species is nonreactive in Melzer's reagent (Fig. $2 \mathrm{a}, \mathrm{d}-\mathrm{f}$ ), and in the latter fungus it stains deep orange brown in this reagent. Finally, the oily content of $S$. tortuosa spores is colourless, whereas the oil filling $G$. convolutum spores is deep yellow. Unfortunately, we cannot support the unambiguous morphological separateness of the two species using molecular proofs because $G$. convolutum has no DNA markers sequenced and known molecular phylogeny so far, similarly as the other species of this fungal group, except for R. fulva (Berk. \& Broome) C. Walker \& A. Schüßler, R. megalocarpa (D. Redecker) C. Walker \& A. Schüßler, and R. pulvinata (Henn.) C. Walker \& A. Schüßler. Our research revealed that the genus Redeckera is a sister of Sieverdingia (Fig. 1), whose molecular divergence is high (by 10.5-11.9\%).

The morphological analyses discussed here also confirmed our hypothesis that the genus Corymbiglomus should contain only species, whose a common feature is the formation of spores with a single spore wall, in which the innermost component is a relatively thick, colourless, laminate layer that frequently separates from the other spore wall layers, but usually adheres to the inner surface of the subtending hyphal wall in crushed spores (Figs. 3c, d, $\mathrm{f}-\mathrm{h}, 4 \mathrm{~d}-\mathrm{h}$ and $5 \mathrm{a}-\mathrm{d}$ ). Such requirements meet only $C$. corymbiforme, C. globiferum, and $C$. pacificum. The following data presented below clearly justify our conclusion.

Species of Pacispora produce spores with two spore walls, of which the inner wall 2 arises de novo after the full differentiation of wall 1 , forming the spore surface, and wall 2 has no physical contact with wall 1 (Fig. 5e, f; Błaszkowski 1988, 2012; Oehl and Sieverding 2004; Walker et al. 2004). Instead, Fig. H illustrating the spore base of C. corymbiforme (Błaszkowski 2012), pictures of $C$. globiferum (treated as D. globifera; http://fungi. invam.wvu.edu/the-fungi/classification/diversisporaceae/ diversispora/globiferum.html), and Fig. 8 showing a crushed $C$. pacificum spore (Medina et al. 2014) clearly show that the innermost hyaline spore subcellular component [characterized by Błaszkowski (2012) and Morton (http://fungi.invam.wvu.edu/ the-fungi/classification/diversisporaceae/diversispora/ globiferum.html) as spore wall layer 3 in C. corymbiforme and C. globiferum, respectively, and by Medina et al. (2014) as spore wall 2 in $C$. pacificum] is associated with the spore base. Moreover, detailed examination of the subcellular structure of C. corymbiforme spores freshly extracted from single-species cultures, C. globiferum spores extracted from trap cultures and field-collected sandy soils (Błaszkowski and B.T. Goto, pers. observ.), as well as type specimens of $C$. pacificum proved that the innermost spore subcellular component consists of sublayers (laminae) and adheres to the inner surfaces of both spore wall layer 2 (in C. corymbiforme and C. globiferum) or layer 3 (in $C$. pacificum) at the spore base and the penultimate subtending hyphal wall layer, and is present either only at or far below the spore base (Figs. 3c, d, f-h, $4 \mathrm{~d}-\mathrm{h}$ and $5 \mathrm{a}-\mathrm{d}$ ), where it likely begins arising. Thus, the location of the innermost spore subcellular component in the spore subcellular structure of the three species of Corymbiglomus is identical to that of the innermost spore wall component of, for example, Claroideoglomus claroideum (N.C. Schenck \& G.S. Sm.) C. Walker \& A. Schüßler (layer 4) and D. clara (layer 3). Ontogenetic studies of $C$. claroideum spores revealed that the attachment of spore wall layer 4 to the inner surface of the subtending hyphal wall indicates common origin of the subtending hypha and the spore wall, and, consequently, testifies that spore wall layer 4 represents one structure, the spore wall (Stürmer and Morton 1997). Thus, although the ontogeny of the three species of Corymbiglomus discussed here is unknown, the attachment of the innermost spore subcellular component to the penultimate layers of the spore and subtending hyphal walls supports our conclusion that all components of the subcellular spore structure of these species also constitute one spore wall. Finally, the position of the innermost spore wall layer in the subcellular spore structure of Corymbiglomus spp. and, especially, its phenotypic features (a relatively thick, colourless laminate layer; Figs. 3c, d, $\mathrm{f}-\mathrm{h}, 4 \mathrm{~d}-\mathrm{h}$ and $5 \mathrm{a}-\mathrm{d}$ ) suggest that this layer is a synapomorphy.

Interestingly, our preliminary molecular phylogenetic analyses indicated that the position of $C$. corymbiforme among the analyzed members of the Diversisporaceae (Fig. 1) changed depending on the species composition of the outgroup (data not shown). When the outgroup of the analyzed alignment was represented by two sequences of only A. laevis or only $S$. baltica, the position of $C$. corymbiforme was as that 
depicted in Fig. 1. However, when the outgroup was two sequences of only $P$. scintillans, $C$. corymbiforme formed a two-species generic clade with $R$. megalocarpum, a species differing fundamentally in morphology, ecology, and highly distant molecularly (by $12.9 \%$ ) from C. corymbiforme (Błaszkowski 2012; Redecker et al. 2007). Moreover, our sequence comparisons indicated the $C$. corymbiforme clade is divergent from the neighbouring $C$. pacificum clade by 11.4 $13.7 \%$, which is roughly equivalent to intergeneric divergences of other taxa of the Glomeromycota (Blaszkowski et al. 2018a, 2018b; Jobim et al. 2019). Instead, the molecular distance between the sister C. globiferum and C. pacificum clades is at the level of interspecies divergences of AMF, i.e. 4.3-6.0\%. Thus, the analyses and comparisons suggest that the relationship of $C$. corymbiforme with $C$. globiferum and C. pacificum is not only distant but also weak, and that C. corymbiforme could alone occupy a generic clade. This may turn out to be true when at least one other new species will be discovered and its molecular similarity to C. corymbiforme will be higher than to C. pacificum.

Based on available own and literature data, as well as on comparisons of molecular sequences of $S$. tortuosa and the three species retained here in Corymbiglomus with molecular sequences of AMF deposited in public databases, we conclude that these species probably occur rather infrequently on Earth.

However, as indicated in the section "Taxonomy", the intraradical presence of $S$. tortuosa and $C$. globiferum was revealed in environmental studies only based on the partial 28S FJ461850 and FJ461836 sequences, respectively, obtained from spores of these species. Instead, BLAST searches using 18S-ITS-28S sequences of these two species, as well as $C$. corymbiforme, showed no hits. In order to explain this inconsistency, we compared the $S$. tortuosa and C. globiferum 18S-ITS-28S sequences with 18S-ITS-28S sequences of the other AMF contained in the phylogenetic tree showed in Fig. 1. The comparisons indicated that the molecular content particularly strongly distinguishing the three species from the other species of the tree resides outside the $28 \mathrm{~S}$ segment. Moreover, BLAST queries using the 18S CCGAAAGG TGGCCTTTTT, ITS 1 AATAATTTTTTACCCCTCCT TTTGA and ATTATATATAAATTGTATTAAAAATATAC, 5.8S-ITS2 CTAAATATTAATCGTAAAT, and ITS2 ATCTCAGATGGGTTC sequences present in all analyzed 18S-ITS-28S sequences of $C$. globiferum did not show any other member of the Kingdom Fungi. The molecular content strongly diverging $S$. tortuos a from all other representatives of the Glomeromycota and all members of the Kingdom Fungi also resides in the ITS1 and ITS2 parts of the 18S-ITS-28S sequences of this species. Thus, we conclude that the predominance of the molecular power contained in the 18S-ITS segment of the $S$. tortuosa and C. globiferum 18S-ITS-28S sequences is so large that in comparisons it moves these $18 \mathrm{~S}-$ ITS-28S sequences outside the barcodes of these species originally determined by the partial $28 \mathrm{~S}$ FJ461850 and FJ461836 sequences. Therefore, BLAST searches omitted $S$. tortuosa and C. globiferum when the queries were their 18S-ITS-28S sequences.

Our phylogenetic analyses showed that the closest natural (molecular) relative of D. peloponnesiaca is D. clara (Fig. 1), whose morphology is strikingly different than that of the new species (Fig. 6a-h). Compared with all described species of Diversispora, mature $D$. peloponnesiaca spores are darkest in colour, whereas those of $D$. clara are colourless to creamy white (Estrada et al. 2011; Błaszkowski, pers. observ.). The spore wall of both species consists of three layers, but spore wall layer 1 of D. peloponnesiaca is permanent (Fig. $6 \mathrm{~b}-\mathrm{f}$, e), i.e. it does not deteriorate with age as spore wall layer 1 of D. clara, which often is absent (completely sloughed off) in mature spores. Moreover, the adherence of spore wall layers 2 and 3 of $D$. peloponnesiaca is clearly stronger than in D. clara. In D. peloponnesiaca, these spore wall layers rarely separate from one another, even in vigorously crushed spores (Fig. 6b-f, h). Instead, crushing of D. clara spores by applying only moderate pressure usually separates spore wall layers 2 and 3 (Błaszkowski, pers. observ.). Finally, spores of D. peloponnesiaca are ca. 1.5-fold larger when globose, have a ca. 1.9-fold thicker spore wall, and their subtending hypha at the spore base is $1.8-2.3$-fold wider and has a $1.3-1.8$-fold thicker wall.

Morphologically, D. peloponnesiaca most resembles D. jakucsiae Błaszk., T.K. Balázs \& Kovács because spores of the latter species are almost as darkly coloured [reddish yellow (4A7) to brownish red (8C8)] as mature spores of D. peloponnesiaca and the spore wall of both species consists of three permanent layers (Balázs et al. 2015). The only characters separating the two species are the tint and thickness of spore wall layer 1 , and the strength of the adherence of spore wall layers 2 and 3. In D. jakucsiae, spore wall layer 1 is clearly lighter [hyaline to yellowish white (4A2)] and ca. 1.7-fold thinner than in D. peloponnesiaca, and spore wall layer 3 is more loosely associated with the laminate spore wall layer 2 because it usually easily separates from this layer in crushed spores. Most importantly, the two species are highly divergent molecularly from one another: three clades at the species level separate $D$. peloponnesiaca from $D$. jakucsiae in our phylogenetic tree (Fig. 1).

Funding information This work was supported by Conselho Nacional de Desenvolvimento Científico e Tecnológico $(\mathrm{CNPq})$ that provided research grants to BT Goto and financial support in the project "Sporocarpic species of arbuscular mycorrhizal fungi (Glomeromycota): taxonomy, systematic and evolution" (proc.4080112016-5). We also thank Universidade Federal do Rio Grande do Norte for covering the costs of J. Błaszkowski's stay as visiting professor (Internationalization incentive program PPg/UFRN/2017). Thanks are due to the Coordenação de Aperfeiçoamento de Pessoal de Nível Superior (CAPES) for providing PhD scholarships to K. Jobim and K.J.G da Silva. 
Open Access This article is distributed under the terms of the Creative Commons Attribution 4.0 International License (http:// creativecommons.org/licenses/by/4.0/), which permits unrestricted use, distribution, and reproduction in any medium, provided you give appropriate credit to the original author(s) and the source, provide a link to the Creative Commons license, and indicate if changes were made.

\section{References}

Balázs TK, Blaszkowski J, Chwat G, Góralska A, Gaspar BK, Lukacs AF, Kovács GM (2015) Spore-based study of arbuscular mycorrhizal fungi of semiarid sandy areas in Hungary, with Diversispora jakucsiae sp. nov. Mycol Prog 14:1021. https://doi.org/10.1007/ s11557-014-1021-z

Blaschke H (1991) Multiple mycorrhizal associations of individual calcicole host plants in the alpine grass-heath zone. Mycorrhiza 1:31-34. https://doi.org/10.1007/BF00205899

Błaszkowski J (1988) Four new species of the Endogonaceae (Zygomycotina) from Poland. Karstenia 27:37-42. https://doi.org/ 10.29203/ka.1987.252

Błaszkowski J (1995) Glomus corymbiforme, a new species in Glomales from Poland. Mycologia 87:732-737. https://doi.org/10.1080/ 00275514.1995 .12026591

Błaszkowski J (2012) Glomeromycota. W. Szafer Institute of Botany, Polish Academy of Sciences, Kraków

Błaszkowski J, Adamska I, Czerniawska B (2002a) Arbuscular mycorrhizal fungi (Glomeromycota) of the Vistula Bar. Acta Mycol 37: 39-62. https://doi.org/10.5586/am.2002.005

Błaszkowski J, Chwat G, Góralska A, Bobrowska-Chwat A (2015a) Glomus tetrastratosum, a new species of arbuscular mycorrhizal fungi (Glomeromycota). Mycoscience 56:280-286. https://doi.org/ 10.1016/j.myc.2014.08.003

Błaszkowski J, Chwat G (2013) Septoglomus deserticola emended and new combinations in the emended definition of the family Diversisporaceae. Acta Mycol 48(1):89-103. https://doi.org/10. 5586/am.2013.011

Błaszkowski J, Chwat G, Góralska A, Ryszka P, Kovács GM (2015b) Two new genera, Dominikia and Kamienskia, and D. disticha sp. nov. in Glomeromycota. Nova Hedwigia 100:225-238. https://doi. org/10.1127/nova_hedwigia/2014/0216

Błaszkowski J, Chwat G, Góralska A, Ryszka P, Orfanoudakis M (2014) Septoglomus jasnowskae and Septoglomus turnauae, two new species of arbuscular mycorrhizal fungi (Glomeromycota). Mycol Prog 13(4):999-1009. https://doi.org/10.1007/s11557-014-0985-Z

Błaszkowski J, Czerniawska B (2006) The occurrence of arbuscular mycorrhizal fungi of the phylum Glomeromycota in Israeli soils. Acta Soc Bot Pol 75:339-350. https://doi.org/10.5586/asbp.2006.041

Błaszkowski J, Furrazola E, Chwat G, Góralska A, Lukács AL, Kovács GM (2015c) Three new arbuscular mycorrhizal Diversispora species in Glomeromycota. Mycol Prog 14:105. https://doi.org/10. 1007/s11557-015-1122-3

Błaszkowski J, Kovács GM, Gáspár BK, Balázs TK, Buscot F, Ryszka P (2012) The arbuscular mycorrhizal Paraglomus majewskii sp. nov. represents a new distinct basal lineage in Paraglomeraceae (Glomeromycota). Mycologia 104(1):148-156. https://doi.org/10. $3852 / 10-430$

Błaszkowski J, Kozłowska A, Niezgoda P, Goto BT, Dalpé Y (2018a) A new genus, Oehlia with Oehlia diaphana comb. nov. and an emended description of Rhizoglomus vesiculiferum comb. nov. in the Glomeromycotina. Nova Hedwigia 107:501-518. https://doi. org/10.1127/nova_hedwigia/2018/0488
Błaszkowski J, Niezgoda P, Goto BT, Kozłowska A (2018b) Halonatospora gen. nov. with $H$. pansihalos comb. nov. and Glomus bareae sp. nov. (Glomeromycota; Glomeraceae). Botany 96:737-748. https://doi.org/10.1139/cjb-2018-0107

Błaszkowski J, Tadych M, Madej T (2002b) Arbuscular mycorrhizal fungi (Glomales, Zygomycota) of the Błędowska Desert. Acta Soc Bot Pol 71:71-85. https://doi.org/10.5586/asbp.2002.008

Cabello MN (2001) Glomus tortuosum (Glomales), and arbuscularmycorrhizal fungus (AMF) isolated from hydrocarbon-polluled soils. Nova Hedwigia 73:513-520

Clements FE, Shear CL (1931) The genera of fungi. Hafner Publishing Co., New York, USA

de Souza RG, Da Silva DKA, De Mello CMA, Goto BT, Da Silva FSB, Sampaio EVSB, Maia LC (2013) Arbuscular mycorrhizal fungi in revegetated mined dunes. Land Degrad Dev (Print) 24:147-155. https://doi.org/10.1002/ldr.1113

Estrada B, Palenzuela J, Barea J-M, Ruiz-Lozano JM, da Silva GA, Oehl F (2011) Diversispora clara (Glomeromycetes) - a new species from saline dunes in the Natural Park Cabo de Gata (Spain). Mycotaxon 118:73-81. https://doi.org/10.5248/118.73

Gai JP, Christie P, Feng G, Li XL (2006) Twenty years of research on biodiversity and distribution of arbuscular mycorrhizal fungi in China: a review. Mycorrhiza 16:229-239. https://doi.org/10.1007/ s00572-005-0023-8

Gerdemann JW, Trappe JM (1974) The Endogonaceae in the Pacific Northwest. Mycol Mem 5:1-76

Goto BT, Maia LC (2006) Glomerospores: a new denomination for the spore of Glomeromycota, a group molecularly distinct from the Zygomycota. Mycotaxon 96:129-132

Goto BT, Silva GA, Yano Melo AM, Maia LC (2010) Checklist of the arbuscular mycorrhizal fungi (Glomeromycota) in the Brazilian semiarid. Mycotaxon 113:251-254. https://doi.org/10.5248/113. 251

Hall TA (1999) BioEdit: a user-friendly biological sequence alignment editor and analysis program for windows 95/98/NT. Nucleic Acids Symp Ser 41:95-98

Huelsenbeck JP, Ronquist F (2001) MRBAYES: Bayesian inference of phylogenetic trees. Bioinformatics 17:754-755. https://doi.org/10. 1093/bioinformatics/17.8.754

Jobim K, Oliveira BIS, Goto BT (2016) Checklist of the Glomeromycota in the Brazilian savanna. Mycotaxon 131:1-13

Jobim K, Błaszkowski J, Niezgoda P, Kozłowska A, Sz Z, Mleczko P, Chachuła P, Ishikawa NK, Goto BT (2019) New sporocarpic taxa in the phylum Glomeromycota: Sclerocarpum amazonicum gen. et sp. nov. in the family Glomeraceae (Glomerales) and Diversispora sporocarpia sp. nov. in the Diversisporaceae (Diversisporales). Mycol Prog 18:369-384. https://doi.org/10.1007/s11557-01801462-2

Kornerup A, Wanscher JH (1983) Methuen handbook of colour, 3rd edn. E. Methuen, London

Koske RE (1987) Distribution of VA mycorrhizal fungi along a latitudinal temperature gradient. Mycologia 79:55-68. https://doi.org/10.1080/ 00275514.1987.12025370

Koske RE, Walker C (1986) Glomus globiferum: a new species of Endogonaceae with a hyphal peridium. Mycotaxon 26:133-142

Krüger M, Stockinger H, Krüger C, Schüßler A (2009) DNA-based level detection of Glomeromycota: one PCR primer set for all arbuscular mycorrhizal fungi. New Phytol 183:212-223. https://doi.org/10. 1111/j.1469-8137.2009.02835.x

Lanfear R, Calcott B, Ho SYW, Guindon S (2012) PartitionFinder: combined selection of partitioning schemes and substitution models for phylogenetic analyses. Mol Biol Evol 29(6):1695-1701. https://doi. org $/ 10.1093 / \mathrm{molbev} / \mathrm{mss} 020$

Medina J, Cornejo P, Borie F, Meier S, Palenzuela J, Vieira HEE, Ferreira ACA, da Silva GA, Sánchez-Castro I, Oehl F (2014) Corymbiglomus pacificum, a new glomeromycete from a saline 
lakeshore in Chile. Mycotaxon 127:173-183. https://doi.org/10. $5248 / 127.173$

Nagy LG, Kocsube S, Csana Z, Kovacs GM, Petkovits T, Lgyi CV, Papp $\mathrm{T}$ (2012) Re-mind the gap! Insertion - deletion data reveal neglected phylogenetic potential of the nuclear ribosomal internal transcribed spacer (ITS) of fungi. PLoS One 7(11):e49794. https://doi.org/10. 1371/journal.pone.0049794

Oehl F, da Silva GA, Goto BT, Sieverding E (2011) Glomeromycota: three new genera and glomoid species reorganized. Mycotaxon 116:75-120. https://doi.org/10.5248/116.75

Oehl F, Sieverding E (2004) Pacispora, a new vesicular arbuscular mycorrhizal fungal genus in the Glomeromycetes. J Appl Bot 78:72-82

Oehl F, Sieverding E, Ineichen K, Mader P, Boller T, Wiemken A (2003) Impact of land use intensity on the species diversity of arbuscular mycorrhizal fungi in agroecosystems of Central Europe. Appl Environ Microbiol 69:2816-2824. https://doi.org/10.1128/AEM. 69.5.2816-2824.2003

Oliveira-Filho AT, Carvalho DA (1993) Florística e fisionomia da vegetação no extremo norte do litoral da Paraíba. Rev Bras Bot $16: 115-130$

Omar MB, Bollan L, Heather WA (1979) A permanent mounting medium for fungi. Bull Br Mycol Soc 13:31-32. https://doi.org/10.1016/ S0007-1528(79)80038-3

Peel MC, Finlayson BL, McMahon TA (2007) Update world map of the Köppen-Geiger climate classification. Hydrol Earth Syst Sc 11: 1633-1644. https://doi.org/10.5194/hess-11-1633-2007

Posada D (2008) jModelTest: phylogenetic model averaging. Mol Biol Evol 25:1253-1256. https://doi.org/10.1093/molbev/msn083

Redecker D, Raab PA, Oehl F, Camacho FJ, Courtecuisse R (2007) A novel clade of sporocarp-forming species of glomeromycotan fungi in the Diversisporales lineage. Mycol Prog 6:35-44. https://doi.org/ 10.1007/s11557-007-0524-2

Redecker D, Schüßler A, Stockinger H, Stürmer SL, Morton JB, Walker C (2013) An evidence-based consensus for the classification of arbuscular mycorrhizal fungi (Glomeromycota). Mycorrhiza 23: 515-531. https://doi.org/10.1007/s00572-013-0486-y

Schalamuk S, Velazquez S, Chidichimo H, Cabello M (2006) Fungal spore diversity of arbuscular mycorrhizal fungi associated with spring wheat: effect of tillage. Mycologia 98:16-22. https://doi. org/10.1080/15572536.2006.11832708

Schenck NC, Smith GS (1982) Additional new and unreported species of mycorrhizal fungi (Endogonaceae) from Florida. Mycologia 74:7792. https://doi.org/10.2307/3792631

Schüßler A, Krüger M, Walker C (2011) Revealing natural relationships among arbuscular mycorrhizal fungi: culture line BEG47 represents Diversispora epigaea, not Glomus versiforme. PLoS One 6(8): e23333. https://doi.org/10.1371/journal.pone.0023333

Silvestro D, Michalak I (2012) raxmlGUI: a graphical front-end for RAxML. Org Divers Evol 12:335-337. https://doi.org/10.1007/ s13127-011-0056-0

Simmons MP, Ochoterena H, Carr TG (2001) Incorporation, relative homoplasy, and effect of gap characters in sequence-based phylogenetic analyses. Syst Biol 50:454-462. https://doi.org/10.1080/ 106351501300318049

Sridhar KR, Beena KR (2001) Arbuscular mycorrhizal research in coastal sand dunes: a review. Proc Nat Acad Sci India 71:179-205

Stamatakis A (2014) RAxML version 8: a tool for phylogenetic analysis and post-analysis of large phylogenies. Bioinformatics 30:13121313. https://doi.org/10.1093/bioinformatics/btu033

Stockinger H, Peyret-Guzzon M, Koegel S, Bouffaud M-L, Redecker D (2014) The largest subunit of RNA polymerase II as a new marker gene to study assemblages of arbuscular mycorrhizal fungi in the field. PLoS One 9(10):e107783. https://doi.org/10.1371/journal. pone. 0107783

Stürmer SL, Morton JB (1997) Developmental patterns defining morphological characters in spores of four species in Glomus. Mycologia 89:72-81. https://doi.org/10.2307/3761174

Sylvia DM (1986) Spatial and temporal distribution of vesiculararbuscular mycorrhizal fungi associated with Uniola paniculata in Florida foredunes. Mycologia 78:728-734. https://doi.org/10.1080/ 00275514.1986 .12025316

Sylvia DM, Burks JN (1988) Selection of a vesicular-arbuscular mycorrhizal fungus for practical inoculation of Uniola paniculata. Mycologia 80:565-568. https://doi.org/10.1080/00275514.1988. 12025579

Sylvia DM, Will ME (1988) Establishment of vesicular-arbuscular mycorrhizal fungi and other microorganisms on a beach replenishment site in Florida. Appl Environm Microbiol 54:348-352

Symanczik S, Al-Yahya'ei MN, Kozłowska A, Ryszka P, Błaszkowski J (2018) A new genus, Desertispora, and a new species, Diversispora sabulosa, in the family Diversisporaceae (order Diversisporales, subphylum Glomeromycotina). Mycol Prog 17:437-449. https:// doi.org/10.1007/s11557-017-1369-y

Symanczik S, Błaszkowski J, Chwat G, Boller T, Wiemken A, AlYahya'ei MN (2014) Three new species of arbuscular mycorrhizal fungi discovered at one location in a desert of Oman: Diversispora omaniana, Septoglomus nakheelum and Rhizophagus arabicus. Mycologia 106:243-259. https://doi.org/10.3852/106.2.243

Tadych M, Błaszkowski J (2000) Arbuscular fungi and mycorrhizae (Glomales) of the Słowiński National Park, Poland. Mycotaxon $74: 463-483$

Takacs T, Bratek Z (2006) Description of AM fungi species from semiarid open sandy grasslands in Hungary. Acta Bot Hung 48:179-188. https://doi.org/10.1556/ABot.48.2006.1-2.16

Tamura K, Stecher G, Peterson D, Filipski A, Kumar S (2013) MEGA6: molecular evolutionary genetics analysis version 6.0. Mol Biol Evol 30:2725-2729. https://doi.org/10.1093/molbev/mst197

Walker C (1983) Taxonomic concepts in the Endogonaceae: spore wall characteristics in species descriptions. Mycotaxon 18:443-455

Walker C, Błaszkowski J, Schwarzott D, Schüßler A (2004) Gerdemannia gen. nov., a genus separated from Glomus, and Gerdemanniaceae fam. nov., a new family in the Diversisporales based on the former Glomus scintillans. Mycol Res 108(6):707718. https://doi.org/10.1017/S0953756204000346

Wang YY, Vestberg M, Walker C, Hurme T, Zhang X, Lindström K (2008) Diversity and infectivity of arbuscular mycorrhizal fungi in agricultural soils of the Sichuan Province of mainland China. Mycorrhiza 18:59-68. https://doi.org/10.1007/s00572-008-0161-x

Wu C-G, Sylvia DM (1993) Spore ontogeny of Glomus globiferum. Mycologia 85:317-322. https://doi.org/10.1080/00275514.1992. 12026276

Yamato M, Yagame T, Yoshimura Y, Iwase K (2012) Effect of environmental gradient in coastal vegetation on communities of arbuscular mycorrhizal fungi associated with Ixeris repens (Asteraceae). Mycorrhiza 22:623-630. https://doi.org/10.1007/s00572-0120439-x

Young ND, Healy J (2003) GapCoder automates the use of indel characters in phylogenetic analysis. BMC Bioinform 4:6. https://doi.org/ $10.1186 / 1471-2105-4-6$

Publisher's note Springer Nature remains neutral with regard to jurisdictional claims in published maps and institutional affiliations. 